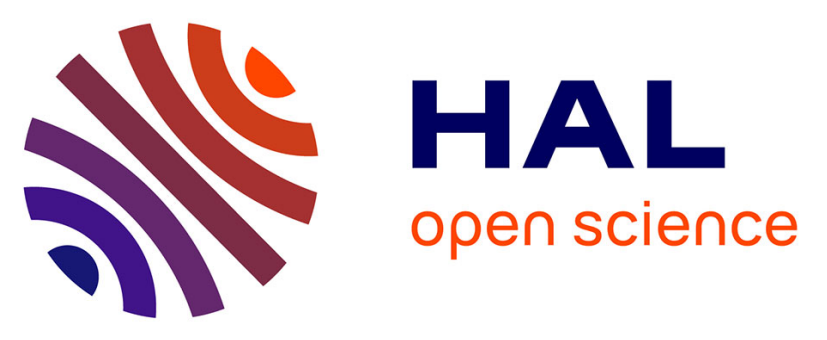

\title{
The PAX-FOXO1s trigger fast trans-differentiation of chick embryonic neural cells into alveolar rhabdomyosarcoma with tissue invasive properties limited by $\mathrm{S}$ phase entry inhibition
}

Gloria Gonzalez Curto, Audrey Der Vartanian, Youcef El-Mokhtar Frarma, Line Manceau, Lorenzo Baldi, Selene Prisco, Nabila Elarouci, Frédéric

Causeret, Daniil Korenkov, Muriel Rigolet, et al.

\section{- To cite this version:}

Gloria Gonzalez Curto, Audrey Der Vartanian, Youcef El-Mokhtar Frarma, Line Manceau, Lorenzo Baldi, et al.. The PAX-FOXO1s trigger fast trans-differentiation of chick embryonic neural cells into alveolar rhabdomyosarcoma with tissue invasive properties limited by S phase entry inhibition. PLoS Genetics, 2020, 16 (11), pp.e1009164. 10.1371/journal.pgen.1009164 . inserm-03016536

\section{HAL Id: inserm-03016536 https://www.hal.inserm.fr/inserm-03016536}

Submitted on 20 Nov 2020

HAL is a multi-disciplinary open access archive for the deposit and dissemination of scientific research documents, whether they are published or not. The documents may come from teaching and research institutions in France or abroad, or from public or private research centers.
L'archive ouverte pluridisciplinaire HAL, est destinée au dépôt et à la diffusion de documents scientifiques de niveau recherche, publiés ou non, émanant des établissements d'enseignement et de recherche français ou étrangers, des laboratoires publics ou privés. 


\title{
The PAX-FOX01s trigger fast trans-differentiation of $\mathrm{cl}$ embryonic neural cells into alveolar rhabdomyosarcol with tissue invasive properties limited by S phase entr inhibition
}

\author{
Gloria Gonzalez Curto ，Audrey Der Vartanian ～，Youcef El-Mokhtar Frarma ， Line Manceau ，Lorenzo Bald \\ Selene Prisco, Nabila Elarouci, Frédéric Causeret, Daniil Korenkov, Muriel Rigolet, Frédéric Aurade, Aurélien De R€ \\ Vincent Contremoulins, Frédéric Relaix, Orestis Faklaris, James Briscoe, Pascale Gilardi-Hebenstreit, Vanessa Rib€
} Published: November 11, 2020 • https://doi.org/10.1371/journal.pgen.1009164

\section{A This is an uncorrected proof.}

\begin{abstract}
The chromosome translocations generating PAX3-FOXO1 and PAX7-FOXO1 chimeric proteins paediatric fusion-positive alveolar subtype of Rhabdomyosarcoma (FP-RMS). Despite the abilit: remodel chromatin landscapes and promote the expression of tumour driver genes, they only ir transformation in vivo. The reason for this is unclear. To address this, we developed an in ovo $\mathrm{n}$ spinal cord progenitors to PAX-FOXO1s. Our data demonstrate that PAX-FOXO1s, but not wild. trans-differentiation of neural cells into FP-RMS-like cells with myogenic characteristics. In para neural pseudo-stratified epithelium into a cohesive mesenchyme capable of tissue invasion. Su FOX01s, similar to wild-type PAX3/7, reduce the levels of CDK-CYCLIN activity and increase th Introduction of CYCLIN D1 or MYCN overcomes this PAX-FOXO1-mediated cell cycle inhibition Together, our findings reveal a mechanism that can explain the apparent limited oncogenicity of factors. They are also consistent with certain clinical reports indicative of a neural origin of FP-F
\end{abstract}

\section{Author summary}

The fusion-positive subtype of rhabdomyosarcoma (FP-RMS) is a rare malignant paediatric car still remain to be deciphered. Out of the gross genetic aberrations found in these cancers, $t(2: 1$ : translocations are the first to appear and lead to the expression of fusion proteins made of the [ or PAX7 and the transactivation domain of FOX01. Both PAX3-FOXO1 and PAX7-FOXO1 have transcription, yet they only inefficiently promote the transformation of healthy cells into tumorige have used chick embryos to monitor in vivo the early response of cells to PAX-FOXO1 chimeric proteins, but not the normal PAX3 and PAX7, transform neural cells into cells with FP-RMS mol also force polarized epithelial neural cells to adopt a mesenchymal phenotype with tissue invasi FOX01s inhibit cell division and hence tumour growth. Genetically re-activating core cell cycle I mediated cell cycle inhibition. Together, our findings bring further support to the idea that the PA 
oncoproteins, whose oncogenicity is limited by negative effects on cell cycle.

Citation: Gonzalez Curto G, Der Vartanian A, Frarma YE-M, Manceau L, Baldi L, Prisco S, $\epsilon$ trigger fast trans-differentiation of chick embryonic neural cells into alveolar rhabdomyosarco properties limited by S phase entry inhibition. PLoS Genet 16(11): e1009164. https://doi.org/

Editor: Gerard Cornelis Grosveld, Department of Genetics, St. Jude Children's Research Hc STATES

Received: May 28, 2020; Accepted: October 2, 2020; Published: November 11, 2020

Copyright: ( $\odot 2020$ Gonzalez Curto et al. This is an open access article distributed under the Attribution License, which permits unrestricted use, distribution, and reproduction in any mec and source are credited.

Data Availability: Transcriptomes of ARMS and ERMS biopsies have been published elsew manuscript; accession numbers GSE92689, E-TABM-1202, E-MEXP-121). These are microl necessary to be able to compare data coming from distinct labs are also provided in $\underline{\mathrm{S} 1 \mathrm{Tab}}$

Funding: VR, FC, FR are staff scientists from the INSERM, PGH is a research director of th UPEC. LM has obtained a fellowship from University of Paris. Work in the lab of VR was sup Contre le Cancer grant (PREAC2016.LCC). Work in FR lab was supported by Agence Natiol grant Crestnetmetabo (ANR-15-CE13-0012-02) and Fondation pour la Recherche Médicale $\mathrm{JB}$ is supported by the Francis Crick Institute, which receives its core funding from Cancer $\mathrm{R}$ Research Council and Wellcome Trust (all under FC001051) and the European Research C had no role in study design, data collection and analysis, decision to publish, or preparation ।

Competing interests: The authors have declared that no competing interests exist.

\section{Introduction}

Transcriptomic landscape remodelling represents a hallmark of tumourigenesis [1]. This is ofter of powerful transcriptional modulators, such as master transcription factors (TFs). Understandin lead to a pathogenic transformation of cells represents a key challenge in cancer research, so i: more physiological model systems to address this question [1,2].

Two related oncogenic TFs, PAX3-FOXO1 and PAX7-FOXO1, are associated with the emerger paediatric alveolar subtype of rhabdomyosarcoma (RMS), named fusion-positive RMS (FP-RM: patients are mostly found in limb extremities and the trunk. These comprise aggregates of roun septa that express, as for other RMS subtypes, undifferentiated embryonic muscle cells marker almost half of FP-RMS patients carry detectable metastases in the lung or bone marrow at the 1 these metastases, together with cancer resistance and emergence of secondary disease are to RMS patients [4].

The in-frame pathognomonic chromosomal translocations, $\mathrm{t}(2 ; 13)(\mathrm{q} 35 ; \mathrm{q} 14)$ or $\mathrm{t}(1 ; 13)$ (p36; $\mathrm{q} 14)$ PAX7 genes to the $3^{\prime}$ end of the FOXO1 gene and lead to the mis-expression of chimeric TFs $n$ PAX3 or PAX7 TFs and the transactivation domain of FOXO1 [3]. Exome sequencing revealed primary genetic lesions in more than $90 \%$ of FP-RMS cases $[\underline{5}, \underline{6}]$. Few somatic mutations are $\mathrm{fc}$ relative fast development of the tumour after the translocations [6]. Furthermore, recurrent gros: 
whole genome duplication, unbalanced chromosomal copy gain, focal amplifications (12q13-q1. heterozygosity notably on $11 \mathrm{p} 15.5$ locus presented by FP-RMS cells [ $[\underline{6}, 6]$ suggest a tumorigeni chromothripsis [7]. The relative contribution of PAX-FOXO1s and of these gross genetic aberral healthy cells into FP-RMS cells is still debated.

A large body of work, mainly focused on PAX3-FOXO1 and aimed at identifying and functionalls target genes, argues the cell fate change characteristic of FP-RMS is driven by PAX-FOXO1s [ $\xi$ from PAX-FOXO1's strong transcriptional transactivation potential, which surpasses that of norr FOXO1 binds to non-coding cis-regulatory genomic modules (CRMs), remodelling chromatin ar $[11,12]$. These CRMs regulate the expression of genes associated with at least 3 traits deleteric $[\underline{8}, \underline{9}, 11,12,14]$. First, several of the target genes encode cell surface proteins which are key cell alteration of the some of them was shown to affect RMS cell motility [15-19]. Second, FP-RMS muscle cell master TFs, which in presence of PAX3-FOXO1 can no longer promote muscle tern PAX-FOXO1s perturb the core cell cycle machinery [요, $\underline{\text { ] }}$. Cross-interactions between PAX3-FO $B C L-X L$ or the senescent factor $\mathrm{p} 16^{\mathrm{INK} 4 \mathrm{~A}}$ promote cell survival [22-24]. PAX3-FOXO1 increase myoblasts and this associated with a downregulation of cyclin-dependent kinase inhibitors (CDF fusion protein displays elevated levels in the $\mathrm{G} 2$ phase which are required for the upregulation c genes [27].

Despite the apparently powerful activity of PAX-FOXO1s, data from animal models have led to 1 proteins do not efficiently trigger FP-RMS formation and spreading [24,28-31]. In excess of 60 । FOXO1 expressing human myoblasts or mesenchymal stem cells to produce significant FP-RM contrasts with the 15 days required for patient derived FP-RMS cells [30-32]. Similarly, driving I muscle embryonic cells from the murine Pax 3 locus induces tumour mass with a reported frequ these in vivo approaches have revealed several parameters enhancing PAX-FOXO1 proteins 0 transgenes in zebrafish indicated that neural derived tissues are more prone than mesodermal when exposed to PAX3-FOXO1, highlighting the differential response of distinct cell lineages [2 models both indicate that a threshold level of PAX3-FOXO1 needs to be reached to observe tur complementing PAX-FOXO1s expression with genetic aberrations promoting cell cycle progres: increased the frequency of tumour formation [28-34]. This was notably achieved by lowering th retinoblastoma protein, RB1; or conversely by ectopically elevating MYCN expression or RAS a

To investigate the molecular mechanisms of oncogenicity in FP-RMS we characterised the initic associated with the transformation of cells expressing PAX3-FOXO1 and PAX7-FOXO1. The gr origin of paediatric cancers [35], the identification of FP-RMS growths in neural tube derived tis: of embryonic neural lineage determinants in FP-RMS cells [9], and the recent use of chick emb/ and invasion $[38,39]$ led us to develop the embryonic chick neural tube as a model system. We repress the molecular hallmarks of neural tube progenitors within 48 hours and impose a molec FP-RMS cells. Concomitantly, PAX-FOXO1s promote an epithelial-mesenchymal transition, cor the adjacent mesoderm in less than 72 hours. Moreover, PAX-FOXO1s limit cell cycle progress activity, which in turn can explain the limited oncogenicity of these fusion TFs.

\section{Results}

Chick neural cells lose their neurogenic potential upon PAX3-FOX01 exposure

To investigate the transformation potential of PAX-FOXO1 proteins, we set out to perform gain c the neural tube of chick embryos. Hamburger and Hamilton $(\mathrm{HH})$ stage 11 chick embryos were expressing PAX3-FOXO1 together with a bi-cistronically encoded nuclear-targeted GFP and all (Fig_1A). For comparison, electroporations with the wild-type versions of $\mathrm{Pax3}$ or the empty $\mathrm{pCl}$ 
addition, the non-electroporated side of the neural tube stood as well as an internal control.

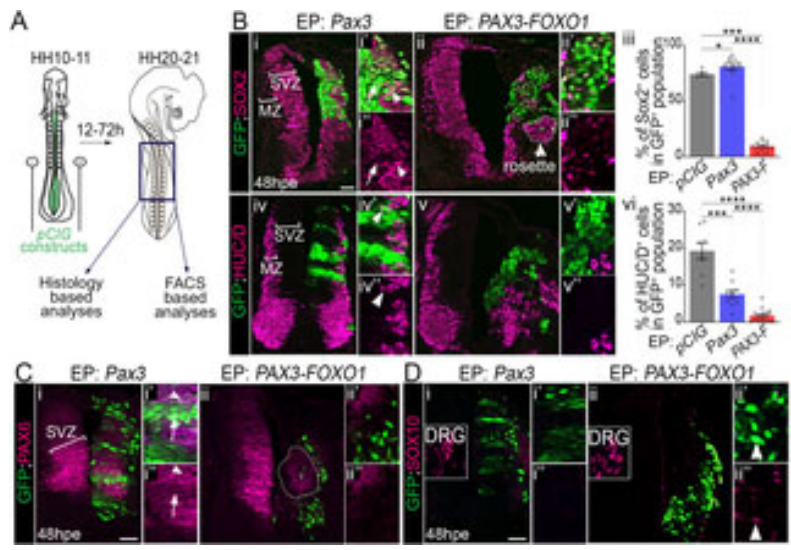

Fig 1. PAX3-FOXO1 switches off generic neurogenic marker expression in chick embryonic spinal cord. (A) Schematics showing $\mathrm{HH} 10-11$ chick embryos filled with $p C / G$ based constructs before b€ to thoracic region (dark blue square) of the electroporated embryos were dissected 12 to 72 or FACS based analyses. (B) (i-ii"; iv-v") Immunodetection of GFP, SOX2 and HUC/D on tr' embryos 48hpe with the indicated plasmids. MZ: Mantle Zone; SVZ: Sub-Ventricular Zone. (i $\mathrm{HUC} / \mathrm{D}^{+}$cells in the $\mathrm{GFP}^{+}$population 48hpe with the indicated plasmids (dots: embryo value Whitney U test: *: $\left.p<0.05,{ }^{* * *}: p<0.001,{ }^{* * * *}: p<0.0001\right)$. (C, D) Immunodetection of GFP, PA) sections of chick embryos 48hpe with the indicated plasmids. DRG: dorsal root ganglia. Arro SOX $10^{+}$; GFP ${ }^{+}$cells. $x^{\prime}$ and $x^{\prime \prime}$ panels are blow-ups of a subset of $x$ panel $\mathrm{GFP}^{+}$cells. Dash rosettes of GFP' ${ }^{-}$cells clustering apart from the SVZ. Arrowheads in $\mathrm{Bi}^{\prime}, \mathrm{i}^{\prime}$ and $\mathrm{Ci}^{\prime}$," point at a PAX6, while those in iv', iv" point at a HUC/D ${ }^{+}$; GFP ${ }^{+}$cell. Arrows in Bi',"' and Ci'," mark GFF SOX2 or PAX6. hpe: hours post-electroporation; scale bars: $50 \mu \mathrm{m}$.

https://doi.org/10.1371/journal.pgen.1009164.g001

We characterised the molecular identity of electroporated cells by assaying the expression of $\mathrm{g}$ $1 \mathrm{C})$. At 48 hours post electroporation (hpe), the neural tube of chick embryos contained SOX2 : to the ventricle and $\mathrm{HUC} / \mathrm{D}^{+}$neurons laterally in the mantle zone (brackets in the non-electropo and 1Ci). PAX3 overexpression did not affect this organisation and cells kept expressing these and 1Ci-i"). This is consistent with PAX3 being present in the spinal progenitors located in the $d$ tube. Yet, in some cells expressing high levels of PAX3, SOX2 and PAX6 expression levels wer 1Ci"). More significantly, spinal cells overexpressing PAX3 produced less $\mathrm{HUC} / \mathrm{D}^{+}$neurons and state (Fig_1Bi-i",iii,iv-iv",vi). This phenotype is reminiscent to that caused by the forced expressic PAX6, suggesting that the extinction of PAX is required in neural progenitors for their terminal $d$ FOXO1 overexpression caused a marked reorganisation on both the ventricular and mantle reg v" and 1Cii-ii'). Strikingly, most PAX3-FOXO1 ${ }^{+}$cells lacked both SOX2 and HUC/D and display€ expression (Fig_1Bii-ii',

We next checked for the expression of SOX10, a marker of neural crest cells (NCC)[41] (Fig 1[ dorsal most part of the neural tube, which they leave to colonize distant embryonic tissues, incli At 48hpe SOX10 ${ }^{+} \mathrm{NCC}$ were present in the skin and the DRG (insets in Fig 1Di,ii). The electror induce SOX10 expression (Fig_1Di-i”) and only rare PAX3-FOXO $1^{+}$cells were positive for this T rules out the possibility of a switch of neural cells into NCC upon exposure to the fusion TF. Tak 
PAX3-FOXO1 is sufficient to divert cells from a generic neurogenic program.

PAX3-FOX01 TFs convert chick neural cells into FP-RMS like-cells

We next tested whether PAX3-FOXO1 expressing cells adopted the identity of alveolar rhabdor of genes that define this identity [9], we combined and re-analysed microarray-based tumour tre PAX3-FOXO1 and 34 PAX7-FOXO1 positive FP-RMS patients and 59 patients affected by othe Tables, S1A Fig) [42-46]. We identified 1194 genes enriched in FP-RMS biopsies; $40 \%$ of whicl identified PAX3-FOXO1 bound cis-regulatory modules (CRM) [11,12] (Fig 2B). This list of genes identified PAX3-FOXO1 dependent FP-RMS markers, such as $A L K, A \bar{R} H G A P 25$, or FGFR4 [9. genes indicated that they encode for developmental regulators of many embryonic lineages knc PAX7 activities (Fig 2C, S4 Table) [48], and not exclusively of the muscle lineage. For instance, the caudal part of amniotes, $A L K$ is found in the spinal cord neurons and peripheral nervous sys expressed by the neural tube and somite cells (cf. chicken expression database http://geisha.ar marks amongst others the somites [50]. The complexity of FP-RMS signature is likely to stem fr expression of master TFs which control the development of distinct lineages in the embryo and/ developmental time points. To illustrate this, we focused on nine TFs, namely EYA2, FOXF1, L1 PAX2, PRDM12 and TFAP2 $\beta$ (Fig_2D). In the myogenic lineage, MEOX1 is the first to be induce specification and the segmentation of the epithelialized somites [51]. LMO4 is transiently induc $\epsilon$ remains longer in these structures where it contributes to the induction of one of the core myogr PITX2 has been shown also to contribute to the induction of MYOD1 but in the limb myoblasts [ myoblasts is required at foetal stages [56]. Only briefly expressed in the somites, FOXF1 marks including the splanchnic mesoderm or the sclerotome [57]. The other TFs, PAX2 [58], PRDM12 neurons of the peripheral and/or central nervous system, so are EYA2 [61], LMO4 [62] and PIT. cells are not simply undifferentiated muscle cells, but rather as cells with their own transcription this combination of TFs in FP-RMS, we quantified their expression levels using either RT-qPCR established human RMS cell lines, including 3 FN-RMS (RD, RDAbl, Rh36) and 4 PAX3-FOXO SJRh30, Rh4, Rh5) (Fig 2D, S1B Fig, S1 Methods, S1-S4 Raw images). All markers assessed with transcript and protein expression levels varying from one cell line to another (Fig_2D, S1B I $P R D M 12$ and TFAP2 $\beta$ displayed significant elevated levels in FP-RMS cells compared to FN-R MYOD1 protein levels did not discriminate FN-RMS and FP-RMS cell lines (S1Biii Fig). FOXF1 cells (Fig 2Diii, higher in FP-RMS Rh5, SJRh30 and Rh4, cell lines than in the other cell lines (S1Biii Fig), repre biomarker and supporting post-translation regulation. Altogether these results further highlight it combination of TFs expressed by FP-RMS [64], which could in turn underpin the transcriptomic they confirmed that the nine TFs chosen can be used to define a FP-RMS identity and to discrir embryonic lineage, notably the myogenic one. 


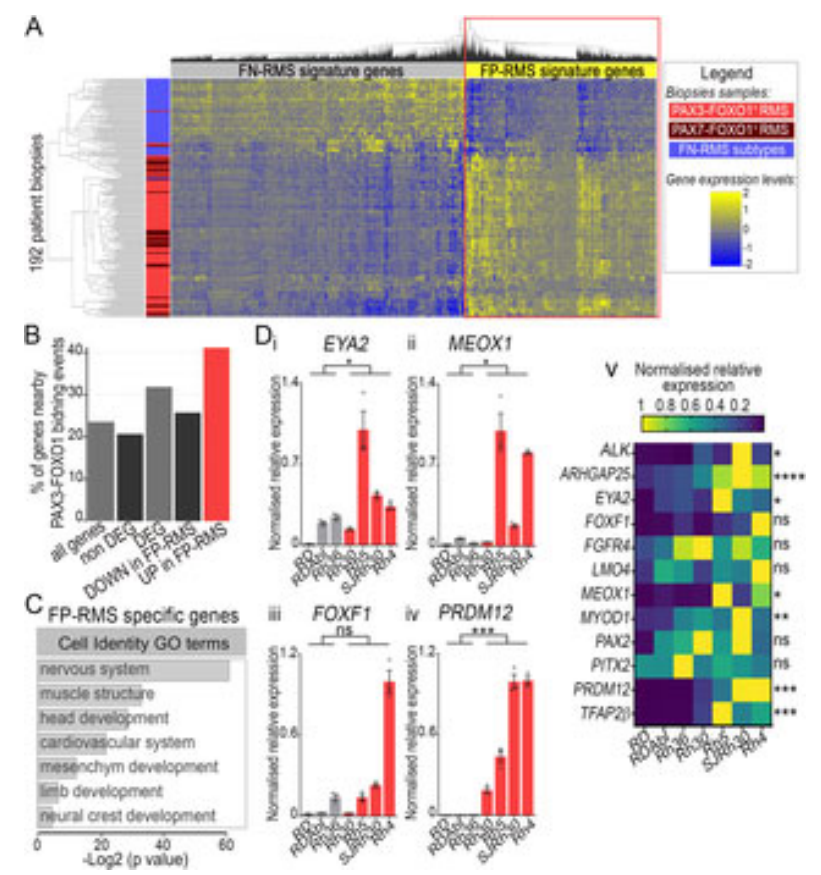

Fig 2. FP-RMS gene signature is composed of TFs marking in the embryo distinct lineages.

(A) Heatmap of hierarchically clustered differentially expressed genes between PAX3-FOXO RMS (red and burgundy rectangles, respectively) and FN-RMS biopsies (blue rectangles). F colour-coded in blue (lower levels) to yellow (higher levels) (See also Method section and S1 in FP-RMS versus FN-RMS are squared in red and named FP-RMS signature genes. (B) $\overline{P \epsilon}$ nearby at least one known PAX3-FOXO1 bound CRM [12] out of those present in our comple genes), non-differentially regulated between FP-RMS and other RMS (non DEG), the differe FP-RMS and other RMS (DEG), downregulated in FP-RMS compared to other RMS (DOWN RMS compared to other RMS (UP in FP-RMS). (C) Gene ontology enrichment for biological specification applied to genes enriched in FP-RMS biopsies. (D) mRNA expression levels of a PAX3-FOXO1 binding event and expressed in various PAX3/7 dependent embryonic tissu€ indicated FN-RMS and FP-RMS cell lines. Levels are relative to TBP transcripts and normali lines. i-iv: dots: biological replicates; bar plots: mean \pm s.e.m.; $n=3$ replicates. v: heatmap c line. Normalised relative expression across samples are colour-coded in blue (lower levels) $t$ way-ANOVA p-values evaluating the similarities between FP-RMS and FN-RMS cells lines: * $p<0.001,{ }^{* * * *}: p<0.0001, n s: p>0.05$.

https://doi.org/10.1371/journal.pgen.1009164.g002

We next assessed the expression of these nine TFs and that of the FP-RMS hallmark genes, $A$ GFP, Pax3 or PAX3-FOXO1 electroporated chick neural cells (Fig 3A). For this, the neural tube dissociated and FACS purified (Fig_1A). RNA from 60 to 80k GFP positive cells was extracted a cDNAs. The expression of all genes was significantly increased by PAX3-FOXO1 and barely alt hybridization for PITX2, LMO4 and MYOD1 performed 24 hours earlier confirmed the ectopic in FOXO1 and the absence of these genes in the neural tube submitted to PAX3 ectopic expressic PITX2 and LMO4 induction was observed in all the electroporated cells (Fig 3Bii-ii', iv-iv'). Inste fusion factor was seen in only half of the electroporated cells (Fig 3Bvi,vi'). In addition, quantific levels after fluorescent immunolabelling of 48hpe embryos showed that PAX3-FOXO1 promote: S2Aii-iii Fig). Conversely, forced expression of PAX3 had no effect on TFAP2 $\alpha^{+}$neurons, but inl neurons (Fig_3Ci-i",iii, S2Ai, 
molecular signature reminiscent of human FP-RMS cells in neural cells, a non-muscle lineage. MYOD1 was induced by PAX3-FOXO1, another member of the core myogenic transcriptional $n$ used as a RMS marker [64], was not induced by the fusion TF, nor by PAX3 (S2B Fig).

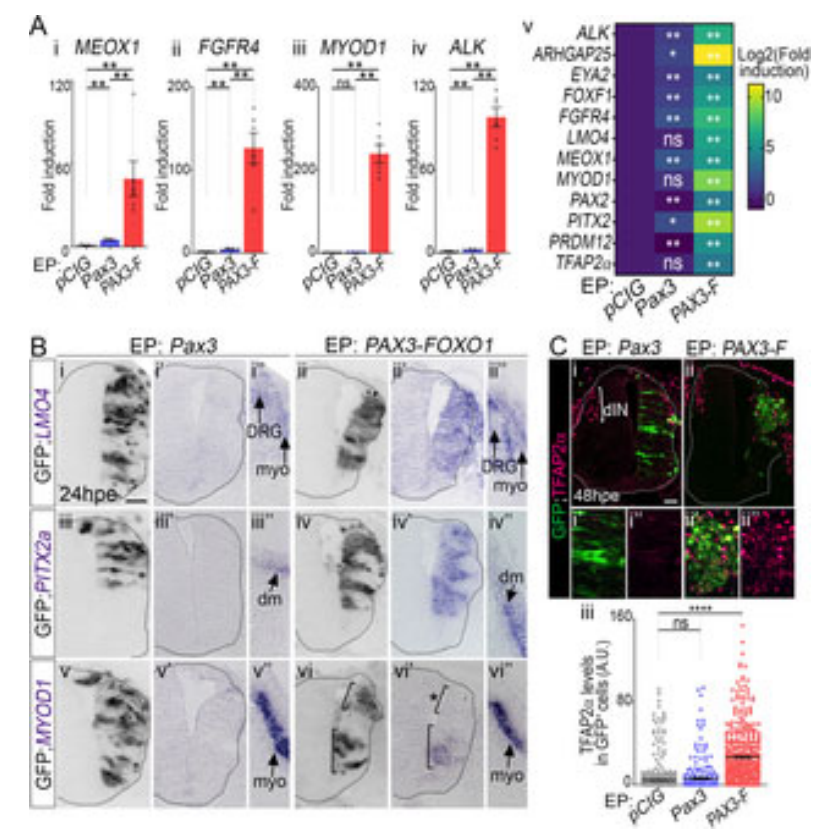

Fig 3. PAX3-FOXO1 converts embryonic neural progenitors into cells harbouring FP-RMS molecular traits (A) mRNA expression levels of FP-RMS hallmark genes in GFP ${ }^{+}$FACS sorted neural tube $C$ plasmids. Levels are relative to TBP transcripts and normalised to $p C / G$ samples mean level bar plots: mean \pm s.e.m; $n>4$ FACS sorts; v: heatmap exhibits mean value over 4 discrete $F$. samples are colour-coded in blue (lower levels) to yellow (higher levels). (B) In situ hybridiza MYOD1 detection and immuno-detection of GFP on transverse sections of chick embryos 24 FOXO1. $x$ and $x$ ' panels represent the same neural tube but in adjacent histological slides. $x$ region of the $x^{\prime}$ sample. dm: dermo-myotome; DRG: dorsal root ganglia, myo: myotome. Upp negative for MYOD1 $\left({ }^{*}\right)$, the lower one cells positive for this TF. PITX2a, LMO4: $\mathrm{n}>9$ embryo: ii') Immunodetection of GFP and TFAP2 $\alpha$ on transverse sections of chick embryos 48hpe w Quantification of expression levels of TFAP2 $\alpha$ in $\mathrm{GFP}^{+}$cells in the spinal cords of chick embr plasmids (dots: cell values; bars: mean \pm s.e.m; $n>5$ embryos). Mann-Whitney $U$ test $p$-value between either $p C / G$ and $P a x 3$ samples or $p C / G$ and PAX3-FOXO1 samples: * $p<0.05,{ }^{* *}: \mathrm{r}$ $\mathrm{p}<0.0001$, ns: $p>0.05$; Scale bars: $50 \mu \mathrm{m}$.

https://doi.org/10.1371/journal.pgen.1009164.g003

PAX3-FOXO1 activates conserved FP-RMS associated enhancers in chick neural cells

The robustness of PAX3-FOXO1 mediated FP-RMS hallmark gene induction in neural cells cou conserved enhancers known to operate in FP-RMS cells [11,12]. To test this idea, we cloned en mouse Met, Meox1, Myod1, Alk, or human CDH3 and PRDM12 genes (S1 Methods). We clone promoter and a reporter gene and co-electroporated them with either $p C / G, P a x 3$, or PAX3-FO; electroporated with the control vector the activity of these enhancers was barely detectable (Fig CRM near the PRDM12 locus that had an endogenous activity in the intermediate-dorsal neura presence of PAX3-FOXO1 all cloned enhancers, except the CDH3 CRM, were transcriptionally 
high expression of the reporter gene (Fig 4iii,,iii', vi, vi', viii, S2Ciii, induction varied between enhancers and from cell to cell. In contrast, PAX3 transcriptional pote। (Fig_4ii,ii',, ,v', vii, S2Cii,ii',iv Fig). It promoted Meox1 CRM activity to levels found in PAX3-FOXC Myod 1 and PRDM12 CRM activity by PAX3 was milder than by PAX3-FOXO1. Finally, PAX3 dic activity. Altogether these results support a model whereby the transformation of neural progenit be mediated by PAX3-FOXO1 co-option of conserved enhancer elements.

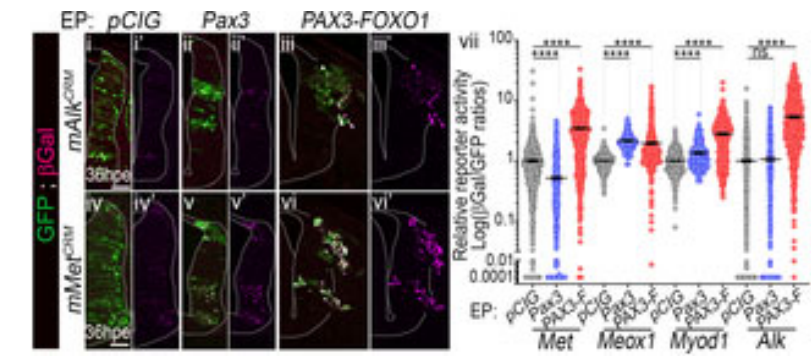

Fig 4. Activation of FP-RMS associated enhancers in chick neural cells by PAX3-FOXO1.

(i-vi') Immunostaining for GFP and $\beta$ Galactosidase ( $\beta \mathrm{Gal}$ ) on transverse sections of chick er $P A X 3-F O X O 1$ and the indicated reporters for the mouse versions of cis-regulatory modules ( FP-RMS cells [12]. (vii) Quantification of $\beta$ Gal levels normalised to that of GFP in cells electr enhancer reporter constructs at 36hpe (dots: cell values; bars: mean \pm s.e.m.; $n>4$ embryos) $* * * *$ : $p<0.0001$, ns: $p>0.05$. Scale bars: $50 \mu \mathrm{m}$.

https://doi.org/10.1371/journal.pggen.1009164.g004

PAX3-FOXO1 promotes epithelial-mesenchymal transition, cell migration and tissue invasion

Paralleling PAX3-FOXO1 mediated cell fate changes, drastic rearrangement of the pseudo-stra (compare Fig 5Aiii,iii' to Fig 5Ai,i'). PAX3-FOXO1 ${ }^{+}$cells adopted a rounded shape, were unever grouped together (Fig 5 Aiii, iii'). Some cells had delaminated either inside the neural tube canal tissue (brackets in Fig 5Aiii, iii'). In addition, neighbouring unelectroporated cells clustered togeth ectopically positioned within the "mantle zone", supporting a sorting of PAX-FOXO1 ${ }^{+}$cells from with dash-lines in Figs $1 \mathrm{Bii}, 1 \mathrm{Cii}$ and $\underline{5 \mathrm{Aiii}}$ ). In contrast, cells electroporated with $p \mathrm{ClG}$ or Pax3 v confined to the neural tube (Fig 5Aii-ii'). In addition, PAX3 overexpression resulted in a thinner $r$ samples (compare Fig 5Ai-ii' to Fig 5Ai, , $^{\prime}$ ). 


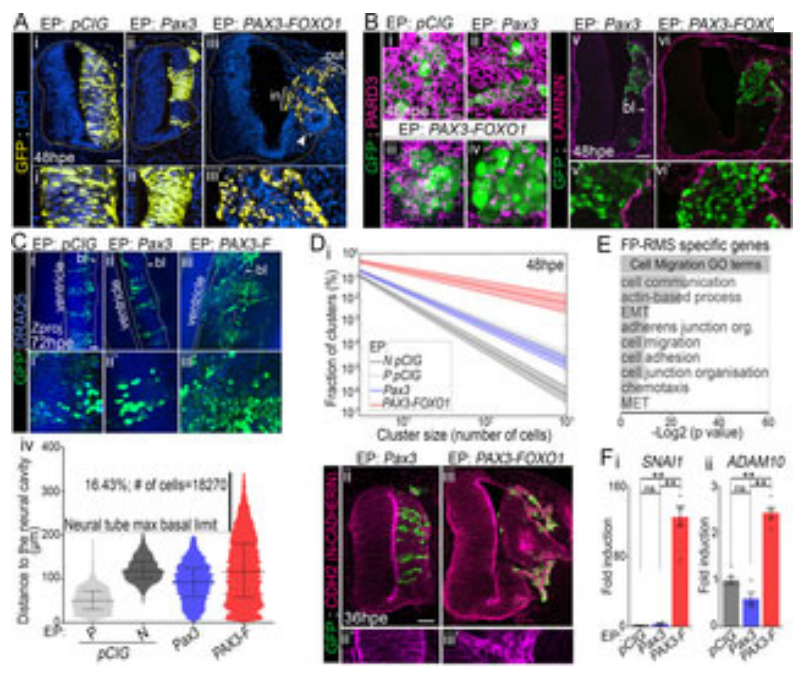

Fig 5. PAX3-FOXO1 transforms neural epithelial cells into a cohesive mesenchyme capable of migration. (A) (i-iii') Immunodetection of GFP and DAPI staining on transverse section of chick embryo plasmids. Brackets in Aiii highlight cells delaminating inside the neural tube (in) or outside of Apical confocal views in open-booked preparation of spinal cords of embryos 48hpe with the immunolabelled with antibodies against GFP and PARD3. Variations in the phenotype are ok FOXO1: (iii) represents 2 of 8 cases analysed, (iv) the rest of cases. (v-vi') Immunodetectior transverse sections of chick embryos 48hpe with the indicated plasmids. (C) (i-iii') Z-projecti embryos immuno-labelled for GFP and stained with DRAQ5. Dotted lines delineate either the neural tube/mesoderm border. (iv) Quantification of the distance of each GFP ${ }^{+}$nuclei from tr the indicated plasmids (Violin plots) P: progenitors and N: neurons. (D) (i) Exponential fit of $t$ function of cluster size at 48hpe in discrete sample types. (ii-iii') Immunodetection of GFP ar sections of chick embryos 48hpe with the indicated plasmids. (E) Gene ontology enrichment linked cell migration and adhesion applied to genes enriched in FP-RMS biopsies. EMT: epitl MET: mesenchymal to epithelial transition. (F) (i-ii) Levels of mRNA expression of the indical assayed by RT-qPCR on GFP ${ }^{+}$FACS sorted neural tube cells 48hpe with $p C / G, P a x 3$ and $P$. to TBP transcripts and normalised to $p C I G$ samples mean level (dots: value for a single RNA Whitney U test $p$-value: *: $p<0.05,{ }^{* *}: p<0.01$, ns: $\left.p>0.05\right)$. $x$ ' and $x "$ panels are blow-ups of a basal lamina. Scale bars: $50 \mu \mathrm{m}$, but in D: $10 \mu \mathrm{m}$.

https://doi.org/10.1371/journal.pggen.1009164.go05

To validate these observations, we quantified several parameters in whole embryos stained witl and documented the distribution of several key markers of the epithelial state (S3A Fig, S6 Tabl migration are tightly connected to cell shape (e.g. [65]). Hence, we started by evaluating that of ellipticity of their nuclei segmented from 3D images (S3B Fig). This parameter reflects the degrt fluctuated between 0.4 and 0.42 for $p C / G$ and Pax3 elongated nuclei (S3Bi, ii,, iv Fig). The elliptic substantially smaller; with time this difference was accentuated (S3Biii, iv Fig). PAX3-FOXO1 ce adapted to tissue exploration [65].

We then monitored the orientation of the major axis of the ellipsoid fit of $\mathrm{GFP}^{+}$cells using polar

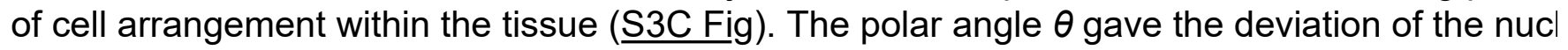
ventral axis, while the azimuthal angle $\varphi$ informed on its orientation within the lateral-medial anc (S3Ci Fig). In 48hpe controls and Pax3 samples, the distribution of $\theta$ and $\varphi$ was similar (S3Cii, $0^{\circ} \mathrm{C}$, consistent with nuclei paralleling the medial-lateral axis of the embryos and apico-basal at 
PAX3-FOXO1 samples $\theta$ and $\varphi$ values displayed a wide distribution (S3Cii,iii Fig), ranging for ir $90^{\circ}$. Hence, PAX3-FOXO1 is able to randomize the nuclei orientation within the spinal tissue.

Alterations in the shape and orientation of the nuclei by PAX3-FOXO1 led us to assess the apic S4A Fig) [66]. We monitored the distribution of the apical determinant PARD3. In open book pre cord, PARD3 labelling revealed a honeycomb-like network at the apical surface (Fig 5Bi). This $r$ for PAX3 although cells harboured less cell-cell contacts (Fig 5Bii). In contrast, PAX3-FOXO1 cr (Fig 5Biii,iv). The loss of apical polarity upon PAX3-FOXO1 forced expression was confirmed b) activated form of BCATENIN (S4Ai-ii" Fig). We next looked at the distribution of the focal adhesi accumulates within the basal regions of control cells (arrowheads in S4Aiii-iv' Fig). Upon PAX3 levels of this protein increased (arrows in S4Aiii' Fig), yet higher levels of $\beta 1$ INTEGRIN were $d \epsilon$ (arrowheads in S4Aiii' Fig). In contrast, the expression of this protein was homogenous through Fig). Hence, upon PAX-FOXO1 expression, neural progenitors lose the polarized distribution of that become distributed evenly throughout their cell membrane.

Because cell polarity is influenced by the extra cellular matrix (ECM) [66], we investigate the dis This key scaffold component of the basal lamina separates the neural tube from the adjacent $m$ samples at $48 \mathrm{hpe}\left(\mathrm{Fig} 5 \mathrm{Bv}, \underline{\mathrm{v}}^{\prime}\right)$. In the presence of PAX3-FOXO1, the basal lamina broke down ( provides, thus, cells with the ability to dismantle tissue barriers. We next tested whether PAX3-F migration, by measuring the distances between the centre of electroporated nuclei and the apic dimensions of $72 \mathrm{hpe}$ embryos (Fig $5 \mathrm{C}$ ). In $p \mathrm{ClG}$ samples, the arrangement of progenitors and $r$ to distinguish these two types of cells. This could not be done in Pax3 samples, probably becau and in PAX3-FOXO1 due to the global transformation of cells (Fig 1B). While, nuclei overexpres tube (compare Fig 5Cii, ii' to Fig 5 Ci, ,i' and Fig 5 Civ), a fraction of PAX $3-F O X O 1^{+}$cells (more tha neural tube and were present within the adjacent tissues (Fig 5Ciii-iii', iv).

To investigate whether cells clustered together, we first measured the distance between neares number of cells belonging to the same cluster (Fig $5 \mathrm{Di}$, see Methods). In control embryos, elect more clustered together than neurons, which is in agreement with the delamination and various subpopulations (Fig 5Di). PAX3 electroporated cells behave similarly to control neural progenitc progenitor like state adopted by PAX3 electroporated spinal cells (Fig_1B). By contrast, in PAX3 tubes, we identified more cells close to each other and bigger groups of cells than in control (Fi! favours the clustering of cells. In agreement with this, PAX3-FOXO $1^{+}$cells expressed high leve was homogenously distributed throughout the cells (Fig 5Diii, iii'), while the gain of PAX3 barely of $\mathrm{CDH} 2$ (ㅌig $\underline{5 \mathrm{Dii}}, \underline{\mathrm{ii}}$ ).

Taken together, these data indicate that PAX3-FOXO1 not only triggers acquisition of FP-RMS i cells with the ability to invade tissues. These phenotypes are likely to be directly regulated by th great number of PAX-FOXO1 targets in FP-RMS cells encoding for tissues remodellers and cel Fig). We notably confirmed that the master epithelial-mesenchymal transition driver SNAI1 and genes displayed elevated levels in presence of PAX3-FOXO1 compared to control and $\mathrm{PAX3}^{+} \mathrm{c}$

PAX3-FOXO1 holds cells in G1 by decreasing CDK-CYCLIN activity

We next assessed the impact of PAX3-FOXO1 on other hallmarks of cancer cells, notably thos [14](ig $\underline{6}, \underline{\text { S5 }}$ and S $\underline{6}$ Figs). 


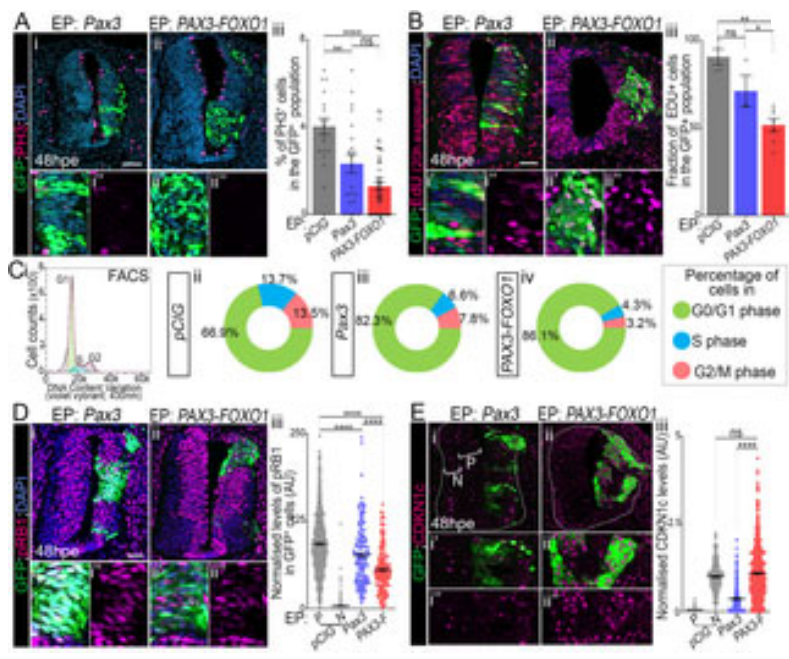

Fig 6. Pax3 and PAX3-FOXO1 limit the entry of cells into $S$ phase.

(A) (i-ii') Immunodetection of GFP, phospho-histone H3 (PH3) and DAPI staining on transve 48hpe with the indicated plasmids. (iii) Quantification of the number of $\mathrm{PH}^{+}$cells in the GFF expressing the indicated plasmids (dots: embryo values; bar plots: mean \pm s.e.m.). (B) (i-ii') and DAPI staining on transverse sections of chick embryos 48hpe with the indicated plasmid before harvest. (iii) Quantification of the number of $\mathrm{EdU}^{+}$cells in the GFP ${ }^{+}$population in emk plasmids (dots: embryo values; bar plots: mean \pm s.e.m.). (C)(i) FACS plots showing DNA cc neural cells stained with vybrant dyecycle violet stain and cell cycle phases gating (green: G1 pink: G2/M phase). (ii-iv) Percentage of cells in the indicated cell cycle phase at 48hpe estal experiments, for individual values see S6Bi-iii Fig and for raw plots see S6A Fig). (D) (i-ii') In phosphorylated form of RB1 (pRB1) and DAPI staining on transverse sections of chick embr' plasmids. (iii) Quantification of pRB1 levels in the GFP ${ }^{+}$cells in embryos expressing the indi in arbitrary unit (AU), bars: mean \pm s.e.m., $n>8$ embryos). (E) (i-ii') Immunodetection of GFF sections of chick embryos 48hpe with the indicated plasmids. P: progenitors; N: neurons. (iii in $\mathrm{GFP}^{+}$cells in embryos expressing the indicated plasmids. P: progenitors; $\mathrm{N}$ : neurons. (dot s.e.m., $n>4$ embryos). $x^{\prime}$ and $x$ " panels are blow-ups of a subset of $x$ panel GFP ${ }^{+}$cells. Mann $0.05,{ }^{* *}: p<0.01,{ }^{* * *}: p<0.001,{ }^{* * *}: p<0.0001$, ns: $p>0.05$. Scale bars: $50 \mu \mathrm{m}$. https://doi.org/10.1371/journal.pgen.1009164.gㅁo6

To assess the proliferative state of cells, we marked mitotic cells using an antibody against the (PH3) (Fig_6A). This indicated PAX3-FOXO1 ${ }^{+}$cells displayed a lower rate of mitosis than contrc a reduction in the number of $\mathrm{PH}^{+}$cells was seen also in $\mathrm{PAX} 3^{+}$cells, albeit to a lesser extent ( that either PAX3-FOXO1 ${ }^{+}$cells were blocked in a cell cycle phase or had a longer cell cycle(s). protein specifically induced cell death by marking activated CASPASE ${ }^{+}$apoptotic cells (S5A F PAX3-FOXO1, a too low proportion of cells (about 2\%) were undergoing cell death at 48hpe to decrease. We next traced cells undergoing DNA synthesis by treating embryos with EdU for 20 all control cells were positive for EdU, while only half of PAX3-FOXO ${ }^{+}$cells (Fig 6 Bii-ii", iii) and

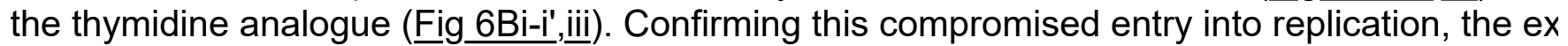
maintenance 2 (MCM2), a protein of the pre-replicative complex was significantly downregulate S5Biii-iii" Fig to S5Bi-i" Fig, S5Biv Fig). The levels of this protein were barely affected by the gai Fig). FACS analyses after labelling cells with a permeable DNA dye (vybrant dyecycle violet sta in presence of PAX3 and PAX3-FOXO1 a larger proportion of cells were in the G1 phase (comp to Fig 6Cii, S6Bi-iii Fig). Taken together, these results support the idea that the gain for PAX3 or 
phase. Similar experiments performed in human fibroblasts indicated that this cell type was alsc FOXO1 ( 6Biv-vi Fig), supporting the idea that PAX3-FOXO1 mediated cell cycle hold is not int

Finally, the phosphorylation of the retinoblastoma-associated RB1 protein being one of the hallr leading to the entry in S phase, we assayed its status (Fig 6D). Both PAX3 and PAX3-FOXO1 d fusion protein to a greater extent than wild-type PAX3 (Fig 6D). Yet, it is worth noting that phosf cells overexpressing the PAX variants and were higher than cells that have left the cell cycle, si Hence, cells are probably not fully arrested. The decrease in phospho-RB1 levels is not linked $t$ RB1, CDK2, CDK6 and CCND1 (S5C Fig). Instead, we identified that amongst the CIP/KIP CDI upregulated by the fusion protein (ig 6 E), a cue potentially explaining the PAX3-FOXO1 media activity.

PAX3-FOXO1 mediated cell cycle inhibition is overcome by CCND1 or MYCN

We then wanted to test whether PAX3-FOXO1-transformed cells could re-enter cell cycle. For tl CDK-CYCLIN activity in PAX3-FOXO1 expressing cells, by forced expression of CYCLIN D1, C cyclin subtype, PAX3 and PAX3-FOXO1 positive cells displayed a mitotic rate, revealed by qual pCIG control embryos at 48hpe (compare Fig_7Ai-ii" to Fig 6Ai-ii", Fig 7Aiii). Accordingly, the ga FOXO ${ }^{+}$cells to incorporate EdU as do controlled cells (compare Fig 7Bi-i" to Fig 6Bii-ii", Fig 7f

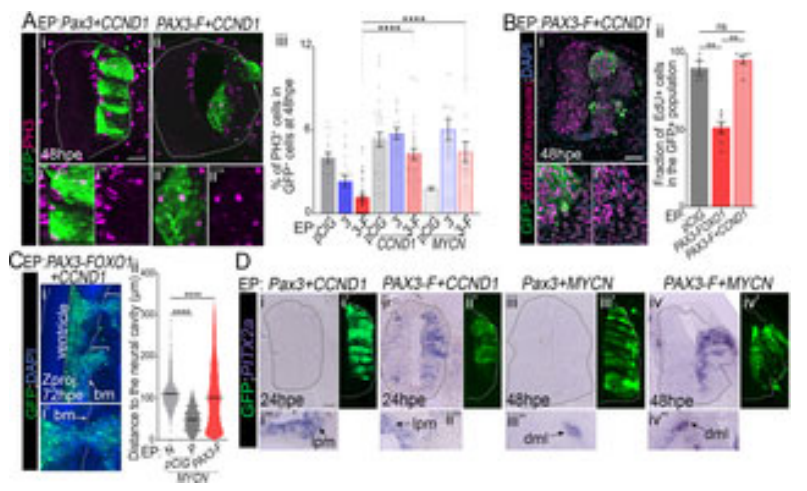

Fig 7. CYCLIN D1 and MYCN rescue PAX-FOXO1 cell cycle inhibition, without affecting the identity and mi (A) (i-ii') Immunodetection of GFP, the phosphorylated form of histone H3 (PH3) and DAPI ई chick embryo at 48hpe with the indicated plasmids. (iii) Quantification of the number of $\mathrm{PH}^{-1}$ embryos expressing the indicated plasmids at 48hpe. (dots: embryo values; bar plots: mean PAX3-FOXO1 samples are the same as in Fig 6Aiii. (B) (i-i') Immunodetection of GFP, EdU section of chick embryos 48hpe with the indicated plasmids and soaked with EDU 20h befor the number of $\mathrm{EdU}^{+}$cells in the $\mathrm{GFP}^{+}$population in embryos expressing the indicated plasm mean \pm s.e.m.). (C) (i-i') Z projection along the dorso-ventral axis of 3D scans of an embryos CCND1. Dotted lines mark the apical cavity and the basal membrane (bm). (ii) Quantificatior nuclei and the apical surface at 72hpe with the indicated plasmids (Violin plots). (D) PITX2 di on transverse sections of chick embryos $24 \mathrm{hpe}$ and 48hpe with the indicated plasmids and ir adjacent section slide. Bottom panels show areas on the embryos and section presented in $t$ expressed, including the lateral plate mesoderm (Ipm) and the dorsal medial lip of the dermo are blow-ups of a subset of $x$ panel GFP ${ }^{+}$cells. Mann-Whitney $U$ test $p$-value: ${ }^{* *}: p<0.01$, ${ }^{* *}$ bars $50 \mu \mathrm{m}$.

https://doi.org/10.1371/journal.pgen.1009164.g007 
We next wondered whether the proto-oncogenes recurrently amplified in FP-RMS cells could al FOXO1 expressing cells. MYCN been amplified in about $10 \%$ of FP-RMS [] ], we forced its expI In the control neural tube, as previously demonstrated [68], MYCN, as opposed to its usual func progenitors in M phase (Fig 7Aiii). In contrast, in presence of PAX3-FOXO1 ${ }^{+}$and MYCN cells $b$

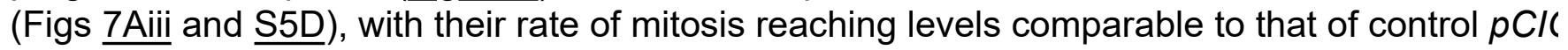

Finally, we checked that upon reactivation of the proliferative activity of PAX3-FOXO1, the spec neural progenitors were maintained. Assaying the migration of cells supported this idea (Fig 7C marker gene PITX2 (ig금).

Together, these results indicated that PAX3-FOXO1 proteins inhibit the entry of cells into S phas decrease in CDK-CYCLIN activity. This inhibition can be overcome by increasing the levels of $C$

PAX7-FOXO1 transformation of spinal progenitors is reminiscent to that by PAX3-FOXO1

Finally, we assessed whether the transformation properties of PAX3-FOXO1 were shared by PA effects of PAX7-FOXO1 on spinal progenitors diverge from that of PAX7 (Fig $\underline{8}$, S7 Fig). To do s we assayed cells $48 \mathrm{hpe}$ with PAX7-FOXO1 or Pax7 using the pan-neuronal markers SOX2 anc genes LMO4, PITX2a, TFAP2a, and Pax2 (Fig 8A, S7A and S7B Fig). Forced expression of PA maintenance of a SOX2 ${ }^{+}$state (S7Ai,i, iii Fig), reduced the formation of $H U C / D^{+}$neurons (Fig 8 . expression of the selected FP-RMS signature genes (Fig 8Aiv-iv",vi, S7Bi, ,i', iii, iii', v-v" Fig). By cc

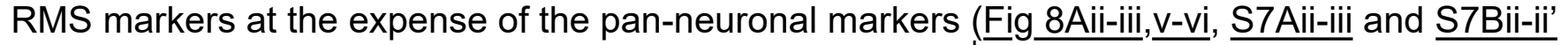
with PAX3-FOXO1. The levels of TFAP2 $\alpha$ in PAX7-FOXO1 ${ }^{+}$cells reached levels similar to thosi (compare Fig 8Avi to Fig 3Ciii), while PAX7-FOXO1 poorly induced PITX2 and LMO4 comparec S7Bii, ii, ,iv, iv' to Fig 3 Bii, ,ii', iv, iv'). This may stem from the differential transcriptional potential betv 


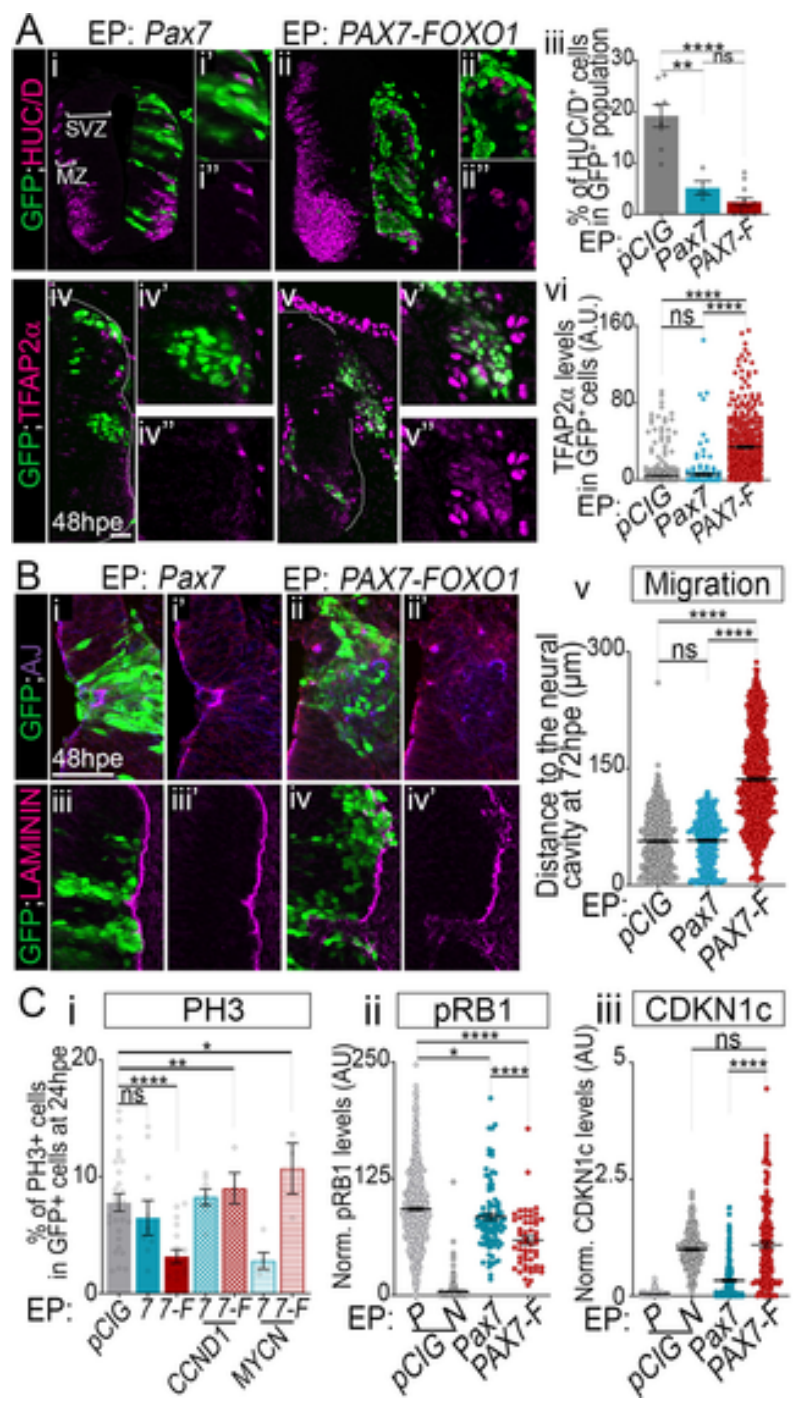

Fig 8. Major traits of PAX7-FOXO1 cellular transformation.

(A) (i-ii', iv-v') Immunodetection of GFP, HUC/D and TFAP2a on transverse section of chick indicated plasmids. (iii, vi) Quantification of the number of $H U C / D^{+}$and TFAP2 $\alpha^{+}$cells in the expressing the indicated plasmids at $48 \mathrm{hpe}$. (dots: embryo values; mean \pm s.e.m.). Data for 1 as presented in Figs 1Bvi and 3Ciii). (B) (i-iv") Immunodetection of GFP, activated bCATENI adherens junctions) and LAMININ on blows-off on $\mathrm{GFP}^{+}$cells of transverse sections of chick indicated plasmids. (v) Quantification of the distance of $\mathrm{GFP}^{+}$nuclei to the apical surface of 1 with the indicated plasmids measured on transverse sections (dots: values in individual cells embryos). (C) (i) Quantification of the number of $\mathrm{PH}^{+}{ }^{+}$cells in the $\mathrm{GFP}^{+}$cells in embryos ex 24hpe. (dots: embryo values; mean \pm s.e.m.. (ii,iii) Quantification of pRB1 (ii) and CDKN1c ( embryos expressing the indicated plasmids (dots: cell values in arbitrary unit (AU), bars: mec for the $p C / G$ samples in $C$ are the same as presented in S5D Fig, Fig 6Diii and Fig 6Eiii. $x$ ' a subset of $x$ panel GFP ${ }^{+}$cells. Mann-Whitney U test $p$-value: ${ }^{* *}: p<0.01,{ }^{* * * *}: p<0.0001$, ns: https://doi.org/10.1371/journal.pgen.1009164.g008

Second, we investigated the tissue remodelling properties of PAX7-FOXO1 and PAX7 (Fig 8B).

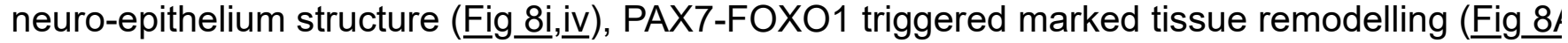
gain of function, PAX7-FOXO1 remodelling was accompanied by the loss of restricted accumuli 
and a breakdown of the basal lamina (Fig 8Biv-iv'). The gain for PAX7 did not alter the distributi Furthermore, PAX7-FOXO ${ }^{+}$cells gained the ability to colonize adjacent tissues, while the force the position of electroporated cells within the embryo (ig $\underline{8 \mathrm{Bv}}$ ).

Finally, quantifying the number of $\mathrm{PH}^{+}$cells and the levels of phospho-RB1 in chick embryos $\epsilon$ FOXO1 were consistent with these PAX variants reducing the ability of progenitors to proliferat $\epsilon$ activity (Fig 8Ci,ii, S7C Fig); with the effects of PAX7-FOXO1 much stronger than that of PAX7. FOXO1 ${ }^{+}$cells was correlated with elevated levels of CDKN1c (Fig 8Ciii, S7Dii-ii" Fig). This was 8Ciii, S7Di-i" Fig). We next checked whether the proliferative behaviour of PAX7-FOXO ${ }^{+}$cells expressing CCND1 or MYCN (Fig_ $8 \mathrm{Ci})$. At 24hpe in presence of either cell cycle regulator PAX $\bar{i}$ rate as great as that of $p \mathrm{ClG}$ samples (iig $\underline{8 \mathrm{Ci}}$ ).

Altogether these data demonstrate that the gross phenotypic traits provided by PAX3-FOXO1 a reminiscent, despite some differences in the molecular response of cells to the two factors. Ass underpinning these differences and how they impact the long term phenotype of cells could pro in the outcome between patients carrying either the $\mathrm{t}(2 ; 13)(\mathrm{q} 35 ; \mathrm{q} 14)$ or $\mathrm{t}(1 ; 13)(\mathrm{p} 36 ; \mathrm{q} 14)$ transk

\section{Discussion}

New markers of FP-RMS and their regulation by the PAX-FOX01s

As for many cancers, the transcriptional state of FP-RMS varies considerably between patients variations in the profile of expression of the embryonic muscle markers, MYOD1 and MYOG [ $\underline{6}$ transcriptome of 192 RMS patients we have been able to revaluate the list of genes marking the distinctive feature of the FP-RMS molecular signature is its association with genes not only regr embryonic muscle cells, but also of other embryonic cell lineages, having in common a PAX3/7 Accordingly, the chromatin landscape of FP-RMS only partially matches that of myoblasts and $r$ PAX3-FOXO1 bound CRMs in the vicinity of $40 \%$ of these FP-RMS associated genes and of PF these CMRs represents a means by which PAX3/7 dependent developmental gene networks ar expressing cells $[11,12,70]$. In addition, the presence of TFs known to also strongly influence th embryonic lineages $[\underline{51}, \underline{53}-\underline{57}, \underline{59}, \underline{62}, \underline{63}, \underline{71}]$ might also contribute to the FP-RMS dysfunctional

Variations in the FP-RMS signature genes is likely to stem from the specific genetic aberrations genetic aberrations, and the cell of origin $[\underline{5}, 6]$. Our data demonstrate that the PAX-FOXO1s are tissue some of FP-RMS associated TFs, while their expression is normally silenced (Figs $\underline{3}$ and stemming from a pioneer transcriptional activity [73], demonstrated for PAX3-FOXO1 in human recruitment of the fusion TF operates largely on closed and transcriptional shut down CRM. PA: CRM nucleosomes and to set up an epigenetic landscape associated with active transcription. I were able to activate de novo CRMs in the embryonic neural tube (Fig $\underline{4}, \underline{\mathrm{S} 2 \mathrm{C}}$ Fig).

In comparison to the PAX-FOXO1s, the wild-type PAX3 or PAX7 are way more sensitive to the 1 while MYOD1 can be induced in embryonic stem cells derived myoblasts by PAX3 [74], we wer transcripts after a gain for PAX3 expression in the neural tube (Fig 2A and 2B). Tissue specific c PAX3/7 TFs haven't yet been revealed. Yet, genetic studies suggest a model where cell fate $\mathrm{sp}_{1}$ dependent transcriptional activation in the myogenic lineage (e.g. [75-77]) and in great means i repression in the neural tube (e.g. [78-80]). As such PAX3 recruitment to the genome of myoblc chromatin marks [75] and PAX3 loss of function phenotypes in these cells can be largely rescut FOXO1 [76]. Conversely, in the neural tube it would act at least partially as a transcriptional rep rescue Pax3 loss of function phenotypes [80]. Even more it can interfere with the normal functic fate changes $([\underline{29}, \underline{80}, \underline{81}]$ and our study). In agreement, PAX3 poorly induced the activity of FP-F 
embryos (Fig 4, S2B Fig). Interestingly, it has been observed that the fusion with FOXO1 inhibit therefore the PAX3-FOXO1 proteins harbour a higher transcriptional potential, which certainly $r$ specific co-factors.

The tissue specific activity of PAX3 can be bypassed, as demonstrated by the induction of MYC PAX3 is provided by RCAS based viral infection for 5 days[83]. This mode of transgenesis expc prolonged expression of the transgenes, as opposed to the electroporated and episomally trans progressively diluted by cell division. This is in line with the idea that the levels of PAX TFs are : response of cells. Exemplifying this, spinal progenitors harbouring different levels of PAX activit: neuronal subtypes [84] and the loss of one single PAX3 allele leads to Waardenburg syndrome, [85].

The use of various promoters to drive the expression of PAX3-FOXO1 in zebrafish or the compi expressed from one or two Pax3 alleles support the idea that PAX-FOXO1 levels are also instri transformation of healthy cells to FP-RMS like cells $[28,29,32]$. This may explain the discrepanc have observed in the chick neural tube and that reported in the neural tube of mice where PAX: the endogenous Pax3 locus or using Pax3 promoter region $[81,84,86]$. In these mouse models, specification of neuronal identities, the neural epithelium folding alterations and in some cases i been reported. In contrast, the presence of both myoblast and non myoblasts associated TFs $\mathrm{W}$ expressing PAX3-FOXO1 and PAX7-FOXO1 support a routing of cells a FP-RMS like state.

Most importantly, our study, taken together with the study by Kendall et al. [29], supports the co cellular subtype from which FP-RMS can originate. Accordingly, $20-40 \%$ of primary tumour mas by NCC, such as the orbit, bladder, para-meningeal, head and neck areas $([41,46,87]$, S1A Fig) report the presence of FP-RMS primary growths in a giant naevus and spinal cord, that are una $[36,37]$. This idea is further supported by the observation that the regulatory regions in the vicini impacted by the $\mathrm{t}(2 ; 13)(\mathrm{q} 35 ; \mathrm{q} 14)$ translocations remain active in the neural tube after the translı origin on the manifestation of the disease and how much it can contribute the FP-RMS heteroge it is tempting to speculate that it will modulate tumour formation incidence, location and histolog

PAX-FOX01s mediated cell cycle inhibition limits the expansion of transformed and metastatic cells

In the light of the cellular phenotypes appearing upon exposure to PAX-FOXO1, we propose the oncogenic drivers, whose activity is likely underpinning the timeline of tumour formation. On the provide cells with tissue remodelling and invasion capacities. This is reminiscent of the transforı TFs, named EMT-TFs [89]. Explaining this, PAX-FOXO1 dependent FP-RMS signature is signif tissue remodelling. It includes notably modulators of RhoGTPases activity, such as ARHGAP25 known to regulate cell-cell and cell-ECM interactions, polarity and migration [90], which are all $r$ exposure (Fig 4). In addition, PAX-FOXO1 tissue remodelling activity could be reinforced by the TFs, such as SNAl1, PRXX1, ETS1/2 [89] (11-S3 Tables, ig느).

On the other hand, our analyses revealed that the oncogenicity of PAX-FOXO1 transformed cel proliferation (Fig $\underline{5}$ ). Such negative effect of PAX-FOXO1s on cell cycle progression is unlikely $t_{1}$ Human myoblasts expressing PAX3-FOXO1 are not to be able to produce colonies within soft $a$ culture for PAX3-FOXO1 ${ }^{+}$NIH3T3 cells to generate such colonies [91], and PAX-FOXO1s ${ }^{+}$hun spend more time in $\mathrm{G} 1$ phase, as do chick neural cells (S3E Fig). These results provide insight FOXO1s with genetic aberrations promoting cell cycle progression, such as the gain of MYCN c CDKN2A, can enhance their tumorigenic potential (Fig $\underline{3}$, Fig $\underline{6})[\underline{28}, 30,34]$. Whether such comf evolution and if so how it is achieved is not known for most cases. Alterations including mutatio deletions and amplifications or structural variations within cell cycle regulators associated with $\mathrm{F}$ 
chromosome translocation is only seen in $30 \%$ of biopsies $[\underline{5}, 6]$. This calls for a better understal underpinning this cell cycle inhibition. The buffered cell cycle progression induced by PAX-FOX could underlie the refractory response of FP-RMS cells to drugs such as CDK2 inhibitors [34] al resurgence of tumours post-treatment [92], as shown for other cancers [2]. We propose that RE PAX-FOXO1 mediated establishment of a dormant state. The decrease in the levels of the phos FOXO1 gain of function points at a decrease in the level of CDK2 activity and explains the arres This is further supported by the elevated levels of CDKN1c (p57 Kip2), a protein that binds to anc was originally shown to cause cell cycle arrest mostly in G1 phase. This hypothesis is also com a complementation with CCND1 (Cyclin D1), an efficient driver to S phase [95]. Strongly suppor a nodal point in PAX-FOXO1 mediated cell cycle regulation, its loss of function have been show the formation of tumours from p53 null cells of the Myf6 embryonic muscle lineage overexpress

Finally, amongst the approaches taken to study FP-RMS development and evolution [28-30,32 recapitulates the invasive and disseminative properties of PAX-FOXO1 expressing cells [92]. A: human grafted cells [38], we believe that it will particularly suited for studying the modes of diss transformed cells. Our model will also provide a means to investigate the molecular networks ar PAX-FOXO1 mediated-latent metastatic state to overt metastasis [97]; and thereby to provide $v$ therapeutics development.

\section{Methods}

Bioinformatics

Transcriptomes of FP-RMS and ERMS biopsies have been published elsewhere [42-46] (acces E-TABM-1202, E-MEXP-121 and data in [45]). Each dataset was based on Affymetrix micro-arr Tables (Sheet 2). Raw probe set signal intensities were normalized independently, using the fro Bioconductor R package [98]. Individual expression matrices were merged and the residual tecl using the ComBat method implemented in the SVA R package [99]. Samples corresponding to presence/absence of PAX3-FOXO1 or PAX7-FOXO1 fusion genes were subset from the originc script. Differential analysis of fusion positive versus negative samples was conducted using the parameters: resp.type $=$ "Two class unpaired", nperms $=100$, random. seed $=37$, testStatistic $=$ delta score lower than 2.3 (FDR 0) where selected for subsequent analysis.

Hierarchical clustering of the normalized transcriptomes was implemented using the heatmap. 2 [101]). PAX3-FOXO1 chIPseq data (GSE19063, Cao 2010) were mapped to human genome (h were called using MACS2 [103] implemented on Galaxy server [104]. Peaks common to the $2 r$ present in the RD cell line samples were selected using BEDtools [105] and annotated to the th [106]. Functional annotation of the differentially expressed genes and the PAX3-FOXO1 putativ analysis tool of the PANTHER Classification System [107] or GSEA [108].

Chick in ovo electroporation

Electroporation constructs based on $p C / G$ ( $p C A G G S-I R E S-N L S-G F P$ ) expression vector [109] I Pax3, Pax7, PAX3-FOX01, PAX7-FOXO1 [80]; MYCN [68]; CCND1 [110]. Reporters for the hul FOXO1 bound enhancers were cloned upstream of the thymidine kinase (tk) promoter and nuCl late promoter (mlp) and $\mathrm{H} 2 \mathrm{~B}$-Turquoise. For detailed cloning strategies see supporting methods $p C / G$ based constructs $(1.5-2 \mu \mathrm{g} / \mu \mathrm{l})$ were electroporated in Hamburger and Hamilton $(\mathrm{HH})$ stas to described protocols [112]. Embryos were dissected at the indicated stage in cold PBS 1X. 
Embryos were fixed with $4 \%$ paraformaldehyde (PFA) for 45 min to $2 \mathrm{hr}$ at $4^{\circ} \mathrm{C}$, cryoprotected b embedded in gelatin, cryosectioned $(14 \mu \mathrm{m})$, and processed for immunostaining [112] or in situ the reagents are provided in the S1 Methods. Immunofluorescence microscopy was carried out microscope. Pictures of in situ hybridisation experiments were then taken with an Axio Observe images were processed with Image $\mathrm{J}$ v.1.43g image analysis software $(\mathrm{NIH})$ and Photoshop 7.C Jose, CA, USA). All quantifications were performed using Image $\mathrm{J}$. $1.43 \mathrm{~g}$ on usually more than transverse sections per embryo. The number of cells positive for a marker per section was esta on between 2 to 6 transverse sections per embryo. The number of sections taken into account 1 the extent of electroporated cells found along the anterior-posterior axis of the embryo. The me: calculated and is represented with a dot on graphs. Fluorescence intensities in GFP ${ }^{+}$cells were of interests whose size was adapted to that of cell nuclei and multi-measurement plugin. These embryos and often in more than 5 embryos, the number of embryos analysed is always given ir intensities, the greatest variations in the data was set between cells and not between embryos. developmental stage of each cells, their localisation within the neural tube and the levels of exp probabilities of similarity between two populations of values (i.e. between two types of chick sar Mann-Whitney $U$ test in GraphPad Prism and all the $p$-values are given in figures legend. All qu Table.

EdU pulse labelling and staining

A solution of EdU 500uM was injected within the neural tube lumen 20h before harvest. Immun performed as described previously [114] and with the Click-it EdU system (Thermo fisher).

Cell dissociation from chick embryos

GFP positive neural tube regions were dissected after a Dispasel-DMEM/F-12 treatment (Stem $37^{\circ} \mathrm{C}, 30 \mathrm{~min}$ ). Single cell suspensions were obtained by 3 minutes incubation in Trypsin-EDTA । mechanical pressure. Inhibition of Trypsin was ensured using with cold foetal bovine serum (FB

RT-quantitative real-time-PCR on FAC sorted cells

$\mathrm{GFP}^{+}$cells were sorted using BD Influx Sorter (BD Biosciences). Total RNA was extracted from RNAqueous-Micro kit with DNAsel (Life technologies) instructions. RNA quality was assessed $k$ DS-11 FX spectrometer). cDNA was synthesized by SuperScript VILO (Life Technologies) acco RT-PCR was performed using the Veriti TM 96- Well Fast Thermal Cycler (Applied Biosystems) with the StepOnePlus ${ }^{\mathrm{TM}}$ real-time PCR system (Applied Biosystems) using SYBR Green detect Primers can be found in S1 Methods. The expression of each gene was normalised to that of $T$. FOXF1, MYOD1, PITX2, RB1, TFAP2 $\alpha$, TFAP2 $\beta$, TBP expressions were assessed in $\mathrm{n}=6(p C$ FOXO1) independent experiments. Other genes were tested in 3 independent experiments per statistical analyses using Mann-Whitney U-test or two-way ANOVA test were performed in Grar

Flow cytometry-based cell cycle analysis

Dissociated cells were stained with 5uM Vybrant DyeCycle violet stain (V35003, Thermo Fisher minutes in the dark. Light scattering parameters were quantified using a Cyan ADP flow cytom $\epsilon$ were processed using Flowjo software v10.7.1 (Becton Dickinson, USA). Representative gating Single cell events were gated by forward scatter (FCS) peak vs Area (S6Ai Fig). Cells were alsc FSC Area vs Side Scatter (S6Aii Fig). FSC arear vs GFP-log properties were used to segregat $\epsilon$ cells from GFP' wild-type cells (S6Aiii Fig). Cell cycle analysis was performed by using the Dea content data with manual constraining $\mathrm{G} 1$ and $\mathrm{G} 2$ range for model fit optimisation (6B Fig). $\mathrm{Gr}$ 


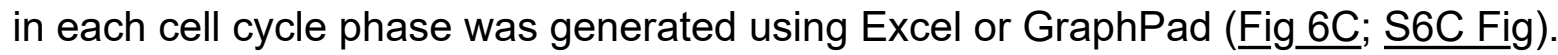

GFP and DNA labelling and imaging 3D chick embryos

Samples were incubated overnight with Atto488 (1/300, Sigma) at $4^{\circ} \mathrm{C}$ for GFP staining, washe 5-10 minutes in DRAQ5 (1/1000, Thermofisher) for DNA staining and finally washed in PBS. Si ventral side in $1 \%$ agarose for 3D imaging. 3D scans of samples were obtained with a 2-photon a femtosecond pulsed Insight Spectra Physics laser, a Carl Zeiss 20x, NA 1.0 (water immersior BioTek) image acquisition software. A single wavelength of $930 \mathrm{~nm}$ was used for exciting all fluo Two GaAsp sensitive photomultipliers allowed simultaneous detection of the two emission lights dichroic mirror $585 \mathrm{~nm}$ and a bandpass filter 525/50nm.

3D images processing and quantitative analyses

Image pre-processing and segmentation were performed using ImageJ and Imaris. Backgrounc channel to eliminate autofluorescence coming from the tissue. Bleach correction normalizing th thickness was performed on DRAQ5 channel stacks of thick samples, notably $72 \mathrm{hpe} \mathrm{samples.} \mathrm{.}$ automatic surface segmentation plugin based on intensity and size ( $<95$ voxels) allowed remov: and dead cells $x, y, z$ coordinates of the centre point, the major axis of their ellipsoid fit, the sphe retrieved for all segmented nuclei. The surfaces encompassing the neural tube, the neural cavit were delineated on the DRAQ5 signal, on $x$-y planes every 3 z-stacks. Distance Transformation segmentation was used to quantify the distance between the centre of the nuclei and this cavity running DBSCAN algorithm on Matlab [115]. Clusters contained a minimum of 3 cells, and the $r$ that belong to the same cluster was fixed to $10 \mu \mathrm{m}$. Cell orientation was established by convertir vector representing the major axis of the ellipsoid fit of GFP positive cells into polar coordinates Graphpad Prism were used for graphic representation and statistical analyses.

Imaging the apical surface of Par3 and GFP labelled spinal cord

Dissected spinal cords were fixed in PFA4\% for $1 \mathrm{~h}$ and washed in PBS. Immunofluorescences Open-book preparation of the samples flatten between a slide and coverslip was imaged using (Leica DMi8: CSU-W1 Yokogawa spinning disk) and MetaMorph (Molecular Devices) image acc

\section{Supporting information}

S1 Fig:

(A) Body locations of RMS biopsies. Locations of FP-RMS (red) and FN-RMS (blue) biopsies assessed in Fig 2A and coming from previous studies [42-46]. ND: Non determined. (B) PITX2 RMS from FN-RMS cells. (i, iii) Pictures of western blots using the indicated antibodies on pro FN-RMS (RD, RDAbl, Rh36) and FP-RMS (Rh3, Rh5, SJRH30, Rh4) cell lines and (ii) normaliz GAPDH. This shows variable levels of PAX3-FOXO1 (i, ii) between FP-RMS cell lines and of M In addition, specific ectopic expression of several PITX2 isoforms (iii) in FP-RMS versus FN-RN to S4 Raw images).

https://doi.org/10.1371/journal.pgen.1009164.s001

(TIF)

S2 Fig_Extended characterization of PAX3-FOXO1's ability to induce FP-RMS signature genes.

(A) (i-ii') Immunodetection of GFP and PAX2 on transverse sections of chick embryos 48hpe w Quantification of PAX2 expression levels in GFP ${ }^{+}$cells in the spinal cords of chick embryos $48 \mathrm{r}$ (dots: single cell values; bars: mean \pm s.e.m.; $\mathrm{n}>5$ embryos). (B) Immunodetection of GFP and 
chick embryos 48hpe with the indicated plasmids. x" panels are views on the myotome (myo) o Immunostaining for GFP, Turquoise direct fluorescence and DAPI staining on transverse sectiol indicated plasmids and a reporter for human $P R D M 12^{C R M}$ and $C D H 3^{C R M}$. (Civ) Quantification that of GFP in cells electroporated with $P R D M 12^{C R M}$ reporter at $24 \mathrm{hpe}$ (dots: single cell values embryos). Mann-Whitney U test $p$-value: ${ }^{* * * *}: p<0.0001$. Scale bars: $50 \mu \mathrm{m}$. https://doi.org/10.1371/journal.pgen.1009164.s002 (TIF)

S3 Fig_Cell shape and orientation dynamics induced by PAX3-FOXO1.

(A) (i-iii) Projection of 3D images of embryos 48hpe with the indicated plasmids, stained with $\mathrm{D}$ (i'-iii') Result of the segmentation performed at the level of the boxes indicated on samples i-iii. electroporated half of the neural tube are transparent yellow, while cell nuclei are coloured. In $p$ segregating progenitor nuclei from neurons is highlighted in transparent red. (iv) $\times$ (medial-later (dorsal-ventral) axes giving the orientation of i-iii samples. (B) (i-iii) Representative 3D shape o scanned whole embryos 48hpe with the indicated plasmids. (iv) Temporal dynamics of the ellipt segmentation of GFP ${ }^{+}$nuclei (as shown in i-iii) in whole-mount embryos (mean \pm s.d., $n>6 \mathrm{emb}$ dimensions of the chick embryos of $\theta$ and $\varphi$ polar angles of the vector (blue arrow) defining the circle). (ii-iii) $\varphi$ (ii) and $\theta$ (iii) possible values and major axes of chick embryos (black circles) an electroporated with the indicated plasmids at 48hpe.

https://doi.org/10.1371/journal.pgen.1009164.s003

(TIF)

S4 Fig. Extended characterization of the epithelial-mesenchymal transition triggered by PAX3-FOXO1.

(A) Immunodetection of GFP, PARD3, activated $\beta C A T E N I N$ (BCAT.) and $\beta 1$-INTEGRIN on trans $48 \mathrm{hpe}$ with the indicated plasmids. In $\mathrm{i}$ and ii, $\mathrm{x}^{\prime}$ and $\mathrm{x}$ " panels are blown up on a subset of $\mathrm{x}$ pal $x$ " are blown up on a subset of $x$ panel GFP ${ }^{+}$and GFP' cells. Arrowheads in $x^{\prime}$ panels point are on the basal side of cells. Arrows in iii' indicate increased levels of $\beta 1$-INTEGRIN at the membr: Scale bars: $50 \mu \mathrm{m}$. (B) Normalized levels of SNAI1 and ADAM10 mRNA assayed by DNA micro biopsies (dots: RNA sample values; bars: mean \pm s.e.m.; Mann-Whitney U test $p$-value: ${ }^{* * * *}$ : $p<$ https://doi.org/10.1371/journal.pgen.1009164.s004 (TIF)

S5 Fig_Cell cycle state of PAX3 and PAX3-FOXO1 overexpressing embryonic spinal cells.

(A) (i-iii") GFP and activated CASPASE3 immunodetection and DAPI staining on transverse s $€$ the indicated plasmids. (iv) Quantification of the number of activated CASPASE3 ${ }^{+}$cells in the $\mathrm{C}$ with the indicated plasmids (dots: embryo values; bar plots: mean \pm s.e.m.). (B) GFP and MCM staining on transverse sections of chick embryos 48hpe with the indicated plasmids. (iv) Quanti cells $48 \mathrm{hpe}$ with the indicated plasmids (dots: single cell values; bar plots: mean \pm s.e.m.; $n>5 \epsilon$ fold changes in the expression of the indicated genes relative to their mean expression in $p C / G$ GFP $^{+}$from chick embryos 48hpe with the indicated constructs. (D) Quantification of the numbel population in embryos $24 \mathrm{hpe}$ with the indicated plasmids (dots: embryo values; bar plots: mean blown up on a subset of $x$ panel GFP ${ }^{+}$cells. Mann-Whitney $U$ test $p$-value: ${ }^{*}: p<0.05,{ }^{* *}: p<0.0$ p>0.05. Scale bars: $50 \mu \mathrm{m}$.

https://doi.org/10.1371/journal.pgen.1009164.s005 (TIF)

S6 Fig_. Cell cycle phases of PAX3 and PAX3-FOXO1 overexpressing cells.

(A) FACS gating strategy in 3 steps using Flowjo: (i) isolation of singlets (FS: forward scatter/ap (ii) selection of cells based on their size (FS: forward scatter) and granularity (SS: side scatter); 
GFP- pools. (B) FACS plots showing DNA content distribution of GFP' $(\mathrm{i}, \mathrm{ii}, \mathrm{iii})$ and $\mathrm{GFP}^{+}$(i',ii',iii') Vybrant DyeCycle Violet stain (black line) and the Dean/Jett/Fox model based cell cycle phases the distribution with the model; pink area: G0/G1 phase, blue area: S phase and green area: G: with the indicated plasmids. (C) Proportion of cells in the indicated cell cycle phase assayed by sorted GFP ${ }^{-}$and GFP ${ }^{+}$chick neural (i-iii) and Human Forskin Fibroblats (HFF; iv-vi) stained witl (dots: mean value on cells analysed on independent FAC sorted samples; bar plots: mean \pm s. $\epsilon$ $\left.0.05,{ }^{* *}: p<0.01,{ }^{* * *}: p<0.001, n s: p>0.05\right)$.

https://doi.org/10.1371/journal.pgen.1009164.s006 (TIF)

S7 Fig. Extended characterization of PAX7-FOXO1 transformation properties.

(A) (i-ii") Immunodetection of GFP and SOX2 on transverse sections of chick embryos 48hpe v Mantle Zone; SVZ: Sub-Ventricular Zone. (iii) Percentage of SOX2 ${ }^{+}$cells in the GFP ${ }^{+}$populatic (dots: embryo values; bar plots: mean \pm s.e.m. (B) In situ hybridization for LMO4 (i-ii"), PITX2a GFP and PAX2 (v-vi") on transverse sections of chick embryos 24hpe (i-iv") or 48hpe (v-vi') with $\mathrm{i}$-iv in display region of the DRG, somite or endoderm regions of $x$ sample. DRG: dorsal root gal myotome. (C) Quantification of the number of $\mathrm{PH}^{+}$cells in the $\mathrm{GFP}^{+}$cells in embryos 48hpe w Immunodetection of GFP and CDKN1c on transverse sections of chick embryos 48hpe with the $\mathrm{N}$ : neurons. $\mathrm{x}^{\prime}$ and $\mathrm{x}$ " panels are blown up on a subset of $\mathrm{x}$ panel GFP ${ }^{+}$cells. Mann-Whitney $\mathrm{U} 1$ ${ }^{* * * *}$ : $p<0.0001$, ns: $p>0.05$. Scale bars: $50 \mu \mathrm{m}$.

https://doi.org/10.1371/journal.pgen.1009164.s007 (TIF)

S1 Methods. Enhancer reporter cloning steps, Primers and antibodies lists.

https://doi.org/10.1371/journal.pgen.1009164.s008

(DOCX)

S1 Table. Gene expression levels in FP-RMS biopsies.

Normalised expression levels of genes assayed using DNA-microarrays in FP-RMS biopsies ( $\mathrm{S}$ https://doi.org/10.1371/journal.pgen.1009164.s009

$(\mathrm{XLSX})$

S2 Table. Gene expression levels in FN-RMS biopsies.

Normalised expression levels of genes assayed using DNA-microarrays in FN-RMS biopsies https://doi.org/10.1371/journal.pgen.1009164.s010

$(\mathrm{XLSX})$

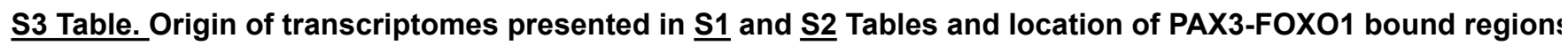
Sheet 1: Origin of the samples and presence or not of PAX3-FOXO1 or PAX7-FOXO1. Sheet 2: CRM (peaks) nearby the genes assayed in Sheet1. Sheet 2: Position of PAX3-FOXO1 bound C https://doi.org/10.1371/journal.pgen.1009164.s011

(XLSX)

S4 Table. Results of the Gene Ontology Biological Process term enrichment analysis.

Sheet 1: Statistics for GO terms related to cell identity, migration and cell cycle regulation enricr RMS. Sheet 2: FP-RMS upregulated genes assigned to cell identity. Sheet 3: FP-RMS upregule migration and adhesion. Sheet 4: FP-RMS upregulated genes assigned to cell cycle regulation https://doi.org/10.1371/journal.pgen.1009164.s012

$(\mathrm{XLSX})$ 
S5 Table. Matrices of the data graphed in the manuscript Figures.

https://doi.org/10.1371/journal.pgen.1009164.s013

(XLSX)

S6 Table. Cell parameters quantified from 3D scans of whole embryos at $48 \mathrm{hpe}$.

Data obtained on a given scan on a given embryo are presented in one independent sheet. Dat presented on a single line.

https://doi.org/10.1371/journal.pgen.1009164.s014

(XLSX)

S1 Raw image. Full western blot membrane presented in S1B Fig_anti-FOXO1.

https://doi.org/10.1371/journal.pgen.1009164.s015

(TIF)

S2 Raw image. Full western blot membrane presented in S1B Fig_anti-GAPDH.

https://doi.org/10.1371/journal.pgen.1009164.s016

(TIF)

S3 Raw image. Full western blot membrane presented in S1B Fig_anti-PITX2.

https://doi.org/10.1371/journal.pgen.1009164.s017

(TIF)

S4 Raw image. Full western blot membrane presented in S1B Fig_anti-MYOD1.

https://doi.org/10.1371/journal.pgen.1009164.s018

(TIF)

\section{Acknowledgments}

We deeply thank the ImagoSeine core facility of Institut Jacques Monod, a member of France-E certified IBiSA. We thank Griselda Wentzinger and Magali Fradet for performing cell sorting at I platform. We are grateful to the people who have provided us with useful tools. We are grateful wording tips. We received plasmids from Sophie Bel Vialar, Marie Henriksson, Elisa Marti, Gwe FP-RMS and ERMS cell lines from Cécile Gauthier-Rouvière.

\section{References}

1. Bradner JE, Hnisz D, Young RA. Transcriptional Addiction in Cancer. Cell. 2017;168:629-643. pmid:2818728: View Article • PubMed/NCBI • Google Scholar

2. Balani S, Nguyen LV, Eaves CJ. Modeling the process of human tumorigenesis. Nat Commun. 2017;8:1-10.

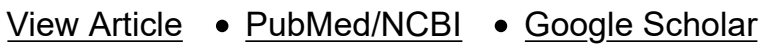

3. Parham DM, Barr FG. Classification of Rhabdomyosarcoma and Its Molecular Basis. Adv Anat Pathol. 2013;

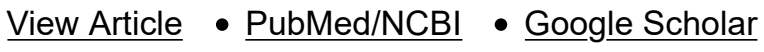

4. Nguyen TH, Barr FG. Therapeutic Approaches Targeting PAX3-FOXO1 and Its Regulatory and Transcriptione Molecules. 2018;23:2798. pmid:30373318

View Article • PubMed/NCBI • Google Scholar 
5. Shern JF, Chen L, Chmielecki J, Wei JS, Patidar R, Rosenberg M, et al. Comprehensive genomic analysis of alterations affecting a common genetic axis in fusion-positive and fusion-negative tumors. Cancer Discov. 201 View Article •

6. Chen L, Shern JF, Wei JS, Yohe ME, Song YK, Hurd L, et al. Clonality and Evolutionary History of Rhabdomy pmid:25768946

View Article $・ \underline{\text { PubMed/NCBI } ・ \text { Google Scholar }}$

7. Luijten MNH, Lee JXT, Crasta KC. Mutational game changer: Chromothripsis and its emerging relevance to $\mathrm{C}_{\mathrm{i}}$ Mutation Research. 2018;777:29-51. pmid:30115429

View Article • PubMed/NCBI - Google Scholar

8. Linardic CM. PAX3-FOXO1 fusion gene in rhabdomyosarcoma. Cancer Lett. 2008;270:10-18. pmid:1845791. View Article • PubMed/NCBI $\bullet$ Google Scholar

9. Marshall AD, Grosveld GC. Alveolar rhabdomyosarcoma-The molecular drivers of PAX3/7-FOXO1-induced pmid:23206814

View Article $・ \underline{\text { PubMed/NCBI }}$ • $\underline{\text { Google Scholar }}$

10. Bennicelli JL, Advani S, Schäfer BW, Barr FG, Schafer BW, Barr FG. PAX3 and PAX7 exhibit conserved cis-a utilize a common gain of function mechanism in alveolar rhabdomyosarcoma. Oncogene. 1999;18:4348-435t

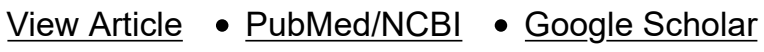

11. Cao L, Yu Y, Bilke S, Walker RL, Mayeenuddin LH, Azorsa DO, et al. Genome-wide identification of PAX3-FK reveals candidate target genes important for development and cancer. Cancer Res. 2010;70:6497-6508. pmi View Article •

12. Gryder BE, Yohe ME, Chou H-C, Zhang X, Marques J, Wachtel M, et al. PAX3-FOXO1 Establishes Myogenic Bromodomain Vulnerability. Cancer Discov. 2017;:CD-16-1297. pmid:28446439

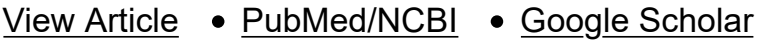

13. Keller C. Pax3:Fkhr interferes with embryonic Pax3 and Pax7 function: implications for alveolar rhabdomyosa 2004;18:2608-2613. pmid:15520281

View Article • PubMed/NCBI • Google Scholar

14. Hanahan D, Weinberg RA. Hallmarks of cancer: The next generation. Cell. 2011;144:646-674. pmid:2137623

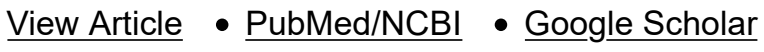

15. Kikuchi K, Tsuchiya K, Otabe O, Gotoh T, Tamura S, Katsumi Y, et al. Effects of PAX3-FKHR on malignant ph Biochem Biophys Res Commun. 2008;365:568-574. pmid:18022385

View Article • $\underline{\text { PubMed/NCBI }}$ - Google Scholar

16. Ginsberg JP, Davis RJ, Bennicelli JL, Nauta LE, Barr FG. Up-regulation of MET but not neural cell adhesion $n$ fusion protein in alveolar rhabdomyosarcoma. Cancer Res. 1998;58:3542-3546. pmid:9721857 


\section{$\underline{\text { View Article }} \cdot \underline{\text { PubMed/NCBI }} \cdot \underline{\text { Google Scholar }}$}

17. Strahm B, Durbin AD, Sexsmith E, Malkin D. The CXCR4-SDF1 $\alpha$ axis is a critical mediator of rhabdomyosarc marrow stroma. Clin Exp Metastasis. 2008;25:1-10. pmid:17768666

View Article $・ \underline{\text { PubMed/NCBI }} \cdot \underline{\text { Google Scholar }}$

18. Jankowski K, Kucia M, Wysoczynski M, Reca R, Zhao D, Trzyna E, et al. Both hepatocyte growth factor (HGF metastatic behavior of human rhabdomyosarcoma cells, but only HGF enhances their resistance to radiocher pmid:14633723

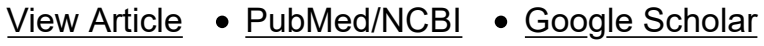

19. Thuault S, Hayashi S, Lagirand-Cantaloube J, Plutoni C, Comunale F, Delattre O, et al. P-cadherin is a direct rhabdomyosarcoma aggressiveness. Oncogene. 2013;32:1876-1887. pmid:22710718

View Article • PubMed/NCBI • Google Scholar

20. Sebire NJ. Myogenin and MyoD1 expression in paediatric rhabdomyosarcomas. J Clin Pathol. 2003;56:412-4 View Article $\bullet \underline{\text { PubMed/NCBI }} \cdot \underline{\text { Google Scholar }}$

21. Calhabeu F, Hayashi S, Morgan JE, Relaix F, Zammit PS. Alveolar rhabdomyosarcoma-associated proteins $P$ the transcriptional activity of MyoD-target genes in muscle stem cells. Oncogene. 2012;32:651-662. pmid:22i

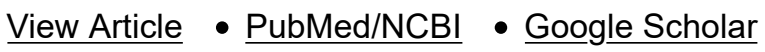

22. Margue CM, Bernasconi M, Barr FG, Schafer BW. Transcriptional modulation of the anti-apoptotic protein BC PAX3 and PAX3/FKHR. Oncogene. 2000;19:2921-2929. pmid:10871843

View Article • PubMed/NCBI • Google Scholar

23. Ayyanathan K, Fredericks WJ, Berking C, Herlyn M, Balakrishnan C, Gunther E, et al. Hormone-dependent tı transcriptional repressor directed at the PAX3-FKHR oncogene. Cancer Res. 2000;60:5803-5814. pmid:1105

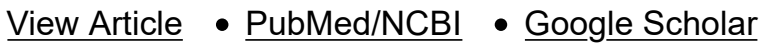

24. Linardic CM, Naini S, Herndon JE, Kesserwan C, Qualman SJ, Counter CM. The PAX3-FKHR fusion gene of p16INK4A to promote bypass of cellular senescence. Cancer Res. 2007;67:6691-6699. pmid:17638879

View Article • PubMed/NCBI • Google Scholar

25. Zhang L, Wang C. PAX3-FKHR transformation increases $26 \mathrm{~S}$ proteasome-dependent degradation of p27Kip expression. J Biol Chem. 2003;278:27-36. pmid:12401804

View Article - $\underline{\text { PubMed/NCBI }}$ - Google Scholar

26. Roeb W, Boyer A, Cavenee WK, Arden KC. PAX3-FOXO1 controls expression of the p57Kip2 cell-cycle regul Acad Sci U S A. 2007;104:18085-18090. pmid:17986608

View Article • PubMed/NCBI • Google Scholar

27. Kikuchi K, Hettmer S, Aslam MI, Michalek JE, Laub W. Wilky BA, et al. Cell-Cycle Dependent Expression of a Mediates Checkpoint Adaptation in Rhabdomyosarcoma. 2014;10. pmid:24453992 


\section{$\underline{\text { View Article }} \cdot \underline{\text { PubMed/NCBI }} \cdot \underline{\text { Google Scholar }}$}

28. Keller C, Arenkiel BR, Coffin CM, El-Bardeesy N, DePinho RA, Capecchi MR. Alveolar rhabdomyosarcomas $\mathrm{i}$ of Ink4a/ARF and Trp53 loss of function. Genes Dev. 2004;18:2614-2626. pmid:15489287

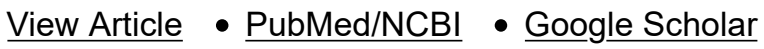

29. Kendall GC, Watson S, Xu L, LaVigne CA, Murchison W, Rakheja D, et al. PAX3-FOXO1 transgenic zebrafist rhabdomyosarcoma tumorigenesis. elife. 2018;7:1-28. pmid:29869612

View Article • $\underline{\text { PubMed/NCBI }}$ - Google Scholar

30. Pandey PR, Chatterjee B, Olanich ME, Khan J, Miettinen MM, Hewitt SM, et al. PAX3-FOXO1 is essential for recurrence in a human myoblast model of rhabdomyosarcoma. J Pathol. 2017;241:626-637. pmid:28138962 $\underline{\text { View Article }}$ - $\underline{\text { PubMed/NCBI }} \cdot \underline{\text { Google Scholar }}$

31. Naini S, Etheridge KT, Adam SJ, Qualman SJ, Bentley RC, Counter CM, et al. Defining the cooperative genet rhabdomyosarcoma. Cancer Res. 2008;68:9583-9588. pmid:19047133

$\underline{\text { View Article }}$ - $\underline{\text { PubMed/NCBI }} \cdot \underline{\text { Google Scholar }}$

32. Ren YX, Finckenstein FG, Abdueva DA, Shahbazian V, Chung B, Weinberg KI, et al. Mouse mesenchymal st alveolar rhabdomyosarcomas by cooperating with secondary mutations. Cancer Res. 2008;68:6587-6597. pr

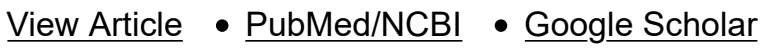

33. Abraham J, Nuñez-Álvarez Y, Hettmer S, Carrió E, Chen H-IHIH, Nishijo K, et al. Lineage of origin in rhabdor response. Genes Dev. 2014;28:1578-1591. pmid:25030697

View Article • PubMed/NCBI • Google Scholar

34. Kikuchi K, Taniguchi E, Chen $\mathrm{H}-\mathrm{IH}$, Svalina MN, Abraham J, Huang ET, et al. Rb1 loss modifies but does not $\mathrm{I}$ Muscle. 2013;3:27. pmid:24274149

View Article • $\underline{\text { PubMed/NCBI }}$ - Google Scholar

35. Marshall GM, Carter DR, Cheung BB, Liu T, Mateos MK, Meyerowitz JG, et al. The prenatal origins of cancer. pmid:24599217

View Article • PubMed/NCBI • Google Scholar

36. Khalatbari MR, Jalaeikhoo H, Hamidi M, Moharamzad Y. Primary spinal epidural rhabdomyosarcoma: a case nervous system: ChNS: official journal of the International Society for Pediatric Neurosurgery. 2012;28:1977-

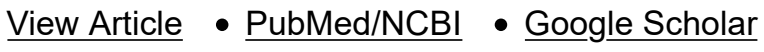

37. Chikhalkar S, Gutte R, Holmukhe S, Khopkar U, Desai S, Gupta S. Alveolar rhabdomyosarcoma arising in a s adult-Case report with review of literature. Int J Dermatol. 2013;52:1372-1375. pmid:23451914

View Article • $\underline{\text { PubMed/NCBI }}$ - Google Scholar

38. Delloye-Bourgeois C, Bertin L, Thoinet K, Jarrosson L, Kindbeiter K, Buffet T, et al. Microenvironment-Driven within Tumors Induces a Switch toward Metastasis in Neuroblastoma. Cancer Cell. 2017;32: 427-443.e8. pm 


\section{$\underline{\text { View Article }} \cdot \underline{\text { PubMed/NCBI }} \cdot \underline{\text { Google Scholar }}$}

39. Komatsu A, Higashi Y, Matsumoto K. Various CAM tumor models. 1st ed. Enzymes. Elsevier Inc.; 2019. https pmid:31727276

40. Bel-Vialar S, Medevielle F, Pituello F. The on/off of Pax6 controls the tempo of neuronal differentiation in the d 2007;305:659-673. pmid:17399698

View Article $\bullet \underline{\text { PubMed/NCBI }}$ - Google Scholar

41. Rogers CD, Jayasena CS, Nie $S$, Bronner ME. Neural crest specification: Tissues, signals, and transcription $f$ 2012;1:52-68. pmid:23801667

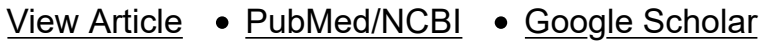

42. Missiaglia E, Williamson D, Chisholm J, Wirapati P, Pierron G, Petel F, et al. PAX3/FOXO1 fusion gene status rhabdomyosarcoma and significantly improves current risk stratification. J Clin Oncol. 2012;30:1670-1677. pr View Article • PubMed/NCBI • Google Scholar

43. Davicioni E, Finckenstein FG, Shahbazian V, Buckley JD, Triche TJ, Anderson MJ. Identification of a PAX-FK molecular classes and determines the prognosis of alveolar rhabdomyosarcomas. Cancer Res. 2006;66:693€

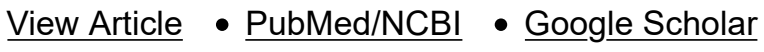

44. Wachtel M, Dettling M, Koscielniak E, Stegmaier S, Treuner J, Simon-Klingenstein K, et al. Gene Expression Subtypes and Detect a Novel t(2;2)(q35;p23) Translocation Fusing PAX3 to NCOA1. Cancer Res. 2004;64:55 View Article •

45. Laé M, Ahn E, Mercado G, Chuai S, Edgar M, Pawel B, et al. Global gene expression profiling of PAX-FKHR fusion-negative embryonal rhabdomyosarcomas. J Pathol. 2007;212:143-151. pmid:17471488

$\underline{\text { View Article }} \cdot \underline{\text { PubMed/NCBI }} \cdot \underline{\text { Google Scholar }}$

46. Williamson D, Missiaglia E, de Reynies A, Pierron G, Thuille B, Palenzuela G, et al. Fusion Gene-Negative Al Molecularly Indistinguishable From Embryonal Rhabdomyosarcoma. J Clin Oncol. 2010;28:2151-2158. pmid:

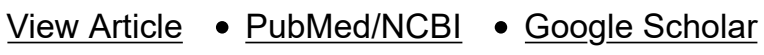

47. Thuault S, Comunale F, Hasna J, Fortier M, Planchon D, Elarouci N, et al. The RhoE/ROCK/ARHGAP25 sign inhibition of Rac activity. Chernoff J, editor. Mol Biol Cell. 2016;27:2653-2661. pmid:27413008

$\underline{\text { View Article }}$ - $\underline{\text { PubMed/NCBI }}$ - Google Scholar

48. Blake JA, Ziman MR. Pax genes: regulators of lineage specification and progenitor cell maintenance. Develor

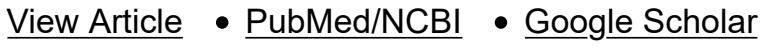

49. Vernersson E, Khoo NKS, Henriksson ML, Roos G, Palmer RH, Hallberg B. Characterization of the expressio mice. Gene Expr Patterns. 2006;6:448-461. pmid:16458083

View Article $\bullet \underline{\text { PubMed/NCBI }} \cdot \underline{\text { Google Scholar }}$ 
50. Wright TJ, Hatch EP, Karabagli H, Karabagli P, Schoenwolf GC, Mansour SL. Expression of mouse fibroblast receptor genes during early inner ear development. Dev Dyn. 2003;228:267-272. pmid:14517998

View Article •

51. Mankoo BS, Skuntz S, Harrigan I, Grigorieva E, Candia A, Wright CVE, et al. The concerted action of Meox $h$ genetic pathways essential for the formation, patterning and differentiation of somites. Development. 2003;13 View Article • PubMed/NCBI • Google Scholar

52. Kenny DA, Jurata LW, Saga Y, Gill GN. Identification and characterization of LMO4, an LMO gene with a nov€ embryogenesis. Proc Natl Acad Sci U S A. 1998;95:11257-11262. pmid:9736723

View Article $\bullet \underline{\text { PubMed/NCBI }} \cdot \underline{\text { Google Scholar }}$

53. Braun T, Rudnicki MA, Arnold $\mathrm{H}-\mathrm{H}$, Jaenisch R. Targeted inactivation of the muscle regulatory gene Myf-5 res perinatal death. Cell. 1992;71:369-382. pmid:1423602

View Article • PubMed/NCBI • Google Scholar

54. Grifone R, Demignon J, Giordani J, Niro C, Souil E, Bertin F, et al. Eya1 and Eya2 proteins are required for hy embryo. Dev Biol. 2007;302:602-616. pmid:17098221

View Article • PubMed/NCBI • Google Scholar

55. L'Honore A, Ouimette J-F, Lavertu-Jolin M, Drouin J. Pitx2 defines alternate pathways acting through MyoD d Development. 2010;137:3847-3856. pmid:20978076

View Article • PubMed/NCBI • Google Scholar

56. L'honoré A, Commère P-H, Ouimette J-F, Montarras D, Drouin J, Buckingham M. Redox Regulation by Pitx2 : Dev Cell. 2014;29:392-405. pmid:24871946

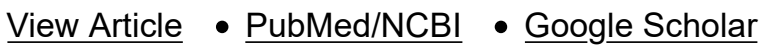

57. Mahlapuu M, Ormestad M, Enerbäck S, Carlsson P. The forkhead transcription factor Foxf1 is required for diff plate mesoderm. Development. 2001;128:155-166. pmid:11124112

View Article • PubMed/NCBI • Google Scholar

58. Nornes HO, Dressler GR, Knapik EW, Deutsch U, Gruss P. Spatially and temporally restricted expression of $F$ Development. 1990;109:797-809. pmid:1977575

View Article • PubMed/NCBI • Google Scholar

59. Thelie A, Desiderio S, Hanotel J, Quigley I, Van Driessche B, Rodari A, et al. Prdm12 specifies V1 interneuror Dbx1 and Nkx6 genes in Xenopus. Development. 2015;142:3416-3428. pmid:26443638

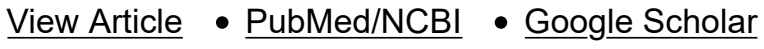

60. Van Otterloo E, Li H, Jones KL, Williams T. AP-2 $\alpha$ and AP-2 $\beta$ cooperatively orchestrate homeobox gene expr Development (Cambridge). 2018. pmid:29229773

View Article - PubMed/NCBI - Google Scholar 
61. Xu PX, Woo I, Her H, Beier DR, Maas RL. Mouse Eya homologues of the Drosophila eyes absent gene requil placode. Development. 1997;124:219-231. pmid:9006082

View Article •

62. Chen H-H, Yip JW, Stewart AFR, Frank E. Differential expression of a transcription regulatory factor, the LIM 1 sensory neurons. Development. 2002;129:4879-4889. pmid:12397097

View Article • PubMed/NCBI • Google Scholar

63. Rozani I, Tsapara G, Witts EC, Deaville SJ, Miles GB, Zagoraiou L. Pitx2 cholinergic interneurons are the sou motor neurons. Sci Rep. 2019;9:4936. pmid:30894556

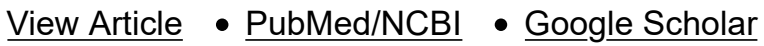

64. Heerema-McKenney A, Wijnaendts LCD, Pulliam JF, Lopez-Terrada D, McKenney JK, Zhu S, et al. Diffuse M Immunohistochemistry is an Independent Marker of Poor Survival in Pediatric Rhabdomyosarcoma: A Tissue Including Correlation With Molecular Phenotype. Am J Surg Pathol. 2008;32:1513-1522. pmid:18708938

View Article • PubMed/NCBI • Google Scholar

65. Hecht I, Bar-EI Y, Balmer F, Natan S, Tsarfaty I, Schweitzer F, et al. Tumor invasion optimization by mesenchy 2015;5:1-12. pmid:26013062

View Article •

66. Roignot J, Peng X, Mostov K. Polarity in Mammalian Epithelial Morphogenesis. Cold Spring Harb Perspect Bi pmid:23378592

View Article $・ \underline{\text { PubMed/NCBI } ・ \text { Google Scholar }}$

67. Lobjois V, Bel-Vialar S, Trousse F, Pituello F. Forcing neural progenitor cells to cycle is insufficient to alter cell. differentiation in the spinal cord. Neural Dev. 2008;3:4. pmid:18271960

$\underline{\text { View Article }}$ - $\underline{\text { PubMed/NCBI }} \cdot \underline{\text { Google Scholar }}$

68. Zinin N, Adameyko I, Wilhelm M, Fritz N. Uhl??n P, Ernfors P, et al. MYC proteins promote neuronal differentii cell division. EMBO Rep. 2014;15:383-391. pmid:24599748

View Article • PubMed/NCBI • Google Scholar

69. Sorensen PHB, Lynch JC, Qualman SJ, Tirabosco R, Lim JF, Maurer HM, et al. PAX3-FKHR and PAX7-FKHF Alveolar Rhabdomyosarcoma: A Report From the Children's Oncology Group. JCO. 2002;20:2672-2679. pmi $\underline{\text { View Article }}$ - $\underline{\text { PubMed/NCBI }}$ - Google Scholar

70. Khan J, Bittner ML, Saal LH, Teichmann U, Azorsa DO, Gooden GC, et al. cDNA microarrays detect activatiol PAX3-FKHR fusion oncogene. Proc Natl Acad Sci U S A. 1999;96:13264-13269. pmid:10557309

View Article • PubMed/NCBI • Google Scholar

71. Van Otterloo E, Li H, Jones KL, Williams T. AP-2 $\alpha$ and AP-2 $\beta$ cooperatively orchestrate homeobox gene expr Development. 2018;145:dev157438. pmid:29229773

View Article - $\underline{\text { PubMed/NCBI }}$ - Google Scholar 
72. Gryder BE, Pomella S, Sayers C, Wu XS, Song Y, Chiarella AM, et al. Histone hyperacetylation disrupts core rhabdomyosarcoma. Nat Genet. 2019;51:1714-1722. pmid:31784732

View Article •

73. Iwafuchi-Doi M, Zaret KS. Cell fate control by pioneer transcription factors. Development. 2016;143:1833-18: View Article • PubMed/NCBI • Google Scholar

74. Magli A, Schnettler E, Rinaldi F, Bremer P, Perlingeiro RCR. Functional Dissection of Pax3 in Paraxial Mesodı Cells. 2013;31:59-70. pmid:23081715

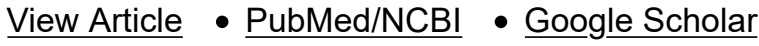

75. Magli A, Baik J, Pota P, Cordero CO, Kwak I-Y, Garry DJ, et al. Pax3 cooperates with Ldb1 to direct local chrc lineage specification. Nat Commun. 2019;10:2316. pmid:31127120

View Article • PubMed/NCBI • Google Scholar

76. Relaix F. The transcriptional activator PAX3-FKHR rescues the defects of Pax3 mutant mice but induces a my ligand-independent activation of Met signaling in vivo. Genes Dev. 2003;17:2950-2965. pmid:14665670

View Article •

77. McKinnell IW, Ishibashi J, Le Grand F, Punch VGJ, Addicks GC, Greenblatt JF, et al. Pax7 activates myogenir methyltransferase complex. Nat Cell Biol. 2008;10:77-84. pmid:18066051

View Article • $\underline{\text { PubMed/NCBI }}$ - Google Scholar

78. Muhr J, Andersson E, Persson M, Jessell TM, Ericson J. Groucho-Mediated Transcriptional Repression Estak Fate in the Ventral Neural Tube. Cell. 2001;104:861-873. pmid:11290324

View Article •

79. Mansouri A, Gruss P. Pax 3 and Pax 7 are expressed in commissural neurons and restrict ventral neuronal ide 1998;78:171-178. pmid:9858722

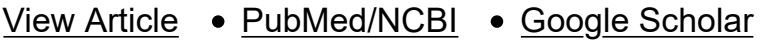

80. Gard C, Gonzalez Curto G, Frarma YEM, Chollet E, Duval N, Auzié V, et al. Pax3- and Pax7-mediated Dbx1 । intermediate spinal interneurons. Dev Biol. 2017;432:24-33. pmid:28625870

View Article • PubMed/NCBI • Google Scholar

81. Finckenstein FG, Davicioni E, Osborn KG, Cavenee WK, Arden KC, Anderson MJ. Transgenic mice expressir muscle development, including ectopic skeletal myogenesis in the developing neural tube. Transgenic Res. 2

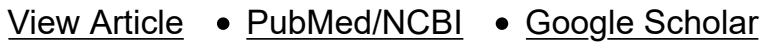

82. Bennicelli JL, Advani S, Schäfer BW, Barr FG. PAX3 and PAX7 exhibit conserved cis-acting transcription repr of function mechanism in alveolar rhabdomyosarcoma. Oncogene. 1999;18:4348-4356. pmid:10439042

View Article • PubMed/NCBI • Google Scholar

83. Maroto M, Reshef R, Münsterberg AE, Koester S, Goulding M, Lassar AB. Ectopic Pax-3 Activates MyoD anc 
and Neural Tissue. Cell. 1997;89:139-148. pmid:9094722

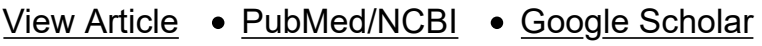

84. Gard C, Gonzalez Curto G, Frarma YE-M, Chollet E, Duval N, Auzié V, et al. Pax3- and Pax7-mediated Dbx1 intermediate spinal interneurons. Dev Biol. 2017;432:24-33. pmid:28625870

View Article • PubMed/NCBI • Google Scholar

85. Boudjadi S, Chatterjee B, Sun W, Vemu P, Barr FG. The expression and function of PAX3 in development anc pmid:29730428

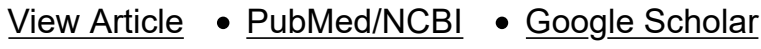

86. Anderson MJ, Shelton GD, Cavenee WK, Arden KC. Embryonic expression of the tumor-associated PAX3-FK developmental functions of Pax3. Proc Natl Acad Sci U S A. 2001;98:1589-1594. pmid:11171995

View Article • PubMed/NCBI • Google Scholar

87. Gouignard N, Andrieu C, Theveneau E. Neural crest delamination and migration: Looking forward to the next pmid:29675839

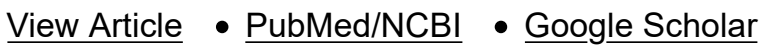

88. Vicente-García C, Villarejo-Balcells B, Irastorza-Azcárate I, Naranjo S, Acemel RD, Tena JJ, et al. Regulatory through interactions between the PAX3 promoter and FOXO1 regulatory elements. Genome Biol. 2017;18. pr $\underline{\text { View Article }} \cdot \underline{\text { PubMed/NCBI }} \cdot \underline{\text { Google Scholar }}$

89. Nieto MA, Huang RYYJ, Jackson RAA, Thiery JPP. Emt: 2016. Cell. 2016;166:21-45. pmid:27368099 View Article • PubMed/NCBI • Google Scholar

90. Hall A. Rho family GTPases. Biochem Soc Trans. 2012;40:1378-1382. pmid:23176484

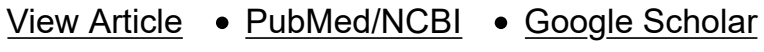

91. Lam PY, Sublett JE. Hollenbach a D, Roussel MF. The oncogenic potential of the Pax3-FKHR fusion protein $r$ helix but not the Pax3 paired-box DNA binding domain. Mol Cell Biol. 1999;19:594-601. pmid:9858583

View Article • PubMed/NCBI • Google Scholar

92. Hettmer S, Li Z, Billin AN, Barr FG, Cornelison DDW, Ehrlich AR, et al. Rhabdomyosarcoma: current challeng therapies. Cold Spring Harb Perspect Med. 2014;4:a025650. pmid:25368019

$\underline{\text { View Article }} \cdot \underline{\text { PubMed/NCBI }} \cdot \underline{\text { Google Scholar }}$

93. Spencer SL, Cappell SD, Tsai FC, Overton KW, Wang CL, Meyer T. XThe proliferation-quiescence decision is at mitotic exit. Cell. 2013;155:369-383. pmid:24075009

$\underline{\text { View Article }} \cdot \underline{\text { PubMed/NCBI }} \cdot \underline{\text { Google Scholar }}$

94. Yan Y, Frisén J, Lee MH, Massagué J, Barbacid M. Ablation of the CDK inhibitor p57 Kip2 results in increasec mouse development. Genes Dev. 1997;11:973-983. pmid:9136926

View Article • 
95. Lange C, Huttner WB, Calegari F. Cdk4/CyclinD1 Overexpression in Neural Stem Cells Shortens G1, Delays and Expansion of Basal Progenitors. Cell Stem Cell. 2009;5:320-331. pmid:19733543

View Article $\bullet \underline{\text { PubMed/NCBI }} \cdot \underline{\text { Google Scholar }}$

96. Naini S, Etheridge KT, Adam SJ, Qualman SJ, Bentley RC, Counter CM, et al. Defining the cooperative genet rhabdomyosarcoma. Cancer Res. 2008;68:9583-9588. pmid:19047133

View Article •

97. Massagué J, Obenauf AC. Metastatic colonization by circulating tumour cells. Nature. 2016;529:298-306. pm

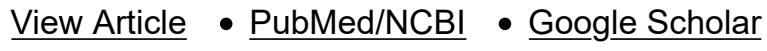

98. McCall MN, Bolstad BM, Irizarry RA. Frozen robust multiarray analysis (fRMA). Biostatistics. 2010;11:242-25: $\underline{\text { View Article }}$ - $\underline{\text { PubMed/NCBI }} \cdot \underline{\text { Google Scholar }}$

99. Leek JT, Storey JD. Capturing heterogeneity in gene expression studies by surrogate variable analysis. PLoS View Article • PubMed/NCBI • Google Scholar

100. Tibshirani R, Seo MJ, Chu G, Narasimhan B, Li J. Significance Analysis of Microarrays for differential express problems. R package version 30. 2018.

View Article $\bullet$ Google Scholar

101. Warnes G, Bolker B, Bonebakker L, Gentleman R, Liaw W, Lumley T, et al. Package "gplots": Various R Progı version 2170. 2016.

View Article • Google Scholar

102. Langmead B, Salzberg SL. Fast gapped-read alignment with Bowtie 2. Nat Methods. 2012;9:357-359. pmid:' $\underline{\text { View Article }}$ - $\underline{\text { PubMed/NCBI }} \cdot \underline{\text { Google Scholar }}$

103. Feng J, Liu T, Qin B, Zhang Y, Liu XS. Identifying ChIP-seq enrichment using MACS. Nat Protoc. 2012;7:172£ $\underline{\text { View Article }} \cdot \underline{\text { PubMed/NCBI }} \cdot \underline{\text { Google Scholar }}$

104. Afgan E, Baker D, van den Beek M, Blankenberg D, Bouvier D, Čech M, et al. The Galaxy platform for access biomedical analyses: 2016 update. Nucleic Acids Res. 2016;44:W3-W10. pmid:27137889

View Article • PubMed/NCBI • Google Scholar

105. Quinlan AR, Hall IM. BEDTools: A flexible suite of utilities for comparing genomic features. Bioinformatics. 20' View Article $\bullet \underline{\text { PubMed/NCBI } ・ \text { Google Scholar }}$

106. McLean CY, Bristor D, Hiller M, Clarke SL, Schaar BT, Lowe CB, et al. GREAT improves functional interpretat 2010;28:495-501. pmid:20436461

View Article • PubMed/NCBI • Google Scholar

107. Mi H, Muruganujan A, Casagrande JT, Thomas PD. Large-scale gene function analysis with the PANTHER cl. 2013;8:1551-1566. pmid:23868073 


\section{$\underline{\text { View Article }} \cdot \underline{\text { PubMed/NCBI }} \cdot \underline{\text { Google Scholar }}$}

108. Subramanian A, Tamayo P, Mootha VK, Mukherjee S, Ebert BL, Gillette MA, et al. Gene set enrichment analy interpreting genome-wide expression profiles. Proc Natl Acad Sci. 2005;102:15545-15550. pmid:16199517

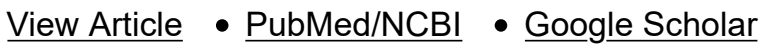

109. Megason SG, McMahon AP. A mitogen gradient of dorsal midline Wnts organizes growth in the CNS. Develor pmid:11959819

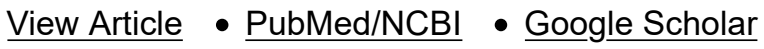

110. Lobjois V, Benazeraf B, Bertrand N, Medevielle F, Pituello F. Specific regulation of cyclins D1 and D2 by FGF progression, patterning, and differentiation during early steps of spinal cord development. Dev Biol. 2004;273 $\underline{\text { View Article }}$ - $\underline{\text { PubMed/NCBI }} \cdot \underline{\text { Google Scholar }}$

111. Hadchouel J, Tajbakhsh S, Primig M, Chang THT, Daubas $P$, Rocancourt $D$, et al. Modular long-range regulat heterogeneity between skeletal muscles in the mouse embryo. Development. 2000;127:4455-4467. pmid:11C $\underline{\text { View Article }}$ - $\underline{\text { PubMed/NCBI }} \cdot \underline{\text { Google Scholar }}$

112. Briscoe J, Pierani A, Jessell TM, Ericson J. A homeodomain protein code specifies progenitor cell identity anc Cell. 2000;101:435-445. pmid:10830170

View Article $・ \underline{\text { PubMed/NCBI }}$ • Google Scholar

113. Yamada T, Pfaff SL, Edlund T, Jessell TM. Control of cell pattern in the neural tube: motor neuron induction bj plate. Cell 1993;73:673-686. pmid:8500163

View Article • PubMed/NCBI • Google Scholar

114. Arai Y, Pulvers JN, Haffner C, Schilling B, Nüsslein I, Calegari F, et al. Neural stem and progenitor cells short production. Nat Commun 2011;2. pmid:21224845

View Article $\bullet \underline{\text { PubMed/NCBI }}$ • Google Scholar

115. Ester M, Kriegel H, Sander J, Xu X. A density-based algorithm for discovering clusters in large spatial databa: International Conference on Knowledge Discovery and Data mining. Elsevier; 1996. p. 226-231. 